\title{
A broadly neutralizing macaque monoclonal antibody against the HIV-1 V3-Glycan patch
}

\author{
Zijun Wang ${ }^{1 \dagger}$, Christopher O Barnes ${ }^{2 \dagger}$, Rajeev Gautam ${ }^{3+}$, Julio C Cetrulo Lorenzi ${ }^{1}$, \\ Christian T Mayer ${ }^{1}$, Thiago Y Oliveira ${ }^{1}$, Victor Ramos ${ }^{1}$, Melissa Cipolla ${ }^{1}$, \\ Kristie M Gordon ${ }^{1}$, Harry B Gristick ${ }^{2}$, Anthony P West ${ }^{2}$, Yoshiaki Nishimura ${ }^{3}$, \\ Henna Raina ${ }^{3}$, Michael S Seaman ${ }^{4}$, Anna Gazumyan', Malcolm Martin ${ }^{3}$, \\ Pamela J Bjorkman², Michel C Nussenzweig ${ }^{1,5}$, Amelia Escolano ${ }^{1 *}$
}

${ }^{1}$ Laboratory of Molecular Immunology, The Rockefeller University, New York, United States; ${ }^{2}$ Division of Biology and Biological Engineering, California Institute of Technology, Pasadena, United States; ${ }^{3}$ Laboratory of Molecular Microbiology, National Institute of Allergy and Infectious Diseases, National Institutes of Health, Bethesda, United States; ${ }^{4}$ Center for Virology and Vaccine Research, Beth Israel Deaconess Medical Center, Boston, United States; ${ }^{5}$ Howard Hughes Medical Institute. The Rockefeller University, New York, United States

*For correspondence: aescolano@rockefeller.edu

${ }^{\dagger}$ These authors contributed equally to this work

Competing interest: See page 16

Funding: See page 16

Received: 11 August 2020

Accepted: 09 October 2020

Published: 21 October 2020

Reviewing editor: Julie Overbaugh, Fred Hutchinson Cancer Research Center, United States

(c) This is an open-access article, free of all copyright, and may be freely reproduced, distributed, transmitted, modified, built upon, or otherwise used by anyone for any lawful purpose. The work is made available under the Creative Commons CCO public domain dedication.
Abstract A small fraction of HIV-1- infected humans develop broadly neutralizing antibodies (bNAbs) against HIV-1 that protect macaques from simian immunodeficiency HIV chimeric virus (SHIV). Similarly, a small number of macaques infected with SHIVs develop broadly neutralizing serologic activity, but less is known about the nature of simian antibodies. Here, we report on a monoclonal antibody, Ab1485, isolated from a macaque infected with SHIVAD8 that developed broadly neutralizing serologic activity targeting the V3-glycan region of HIV-1 Env. Ab1485 neutralizes $38.1 \%$ of HIV-1 isolates in a 42-pseudovirus panel with a geometric mean IC50 of 0.055 $\mu \mathrm{g} / \mathrm{mLI}$ and SHIVAD8 with an IC50 of $0.028 \mu \mathrm{g} / \mathrm{mLI}$. Ab1485 binds the V3-glycan epitope in a glycan-dependent manner. A $3.5 \AA$ cryo-electron microscopy structure of Ab1485 in complex with a native-like SOSIP Env trimer showed conserved contacts with the N332gp120 glycan and gp120 GDIR peptide motif, but in a distinct Env-binding orientation relative to human V3/N332gp120 glycan-targeting bNAbs. Intravenous infusion of Ab1485 protected macaques from a high dose challenge with SHIVAD8. We conclude that macaques can develop bNAbs against the V3-glycan patch that resemble human V3-glycan bNAbs.

\section{Introduction}

Over the last decade, characterization of monoclonal antibodies isolated from HIV-1-infected individuals with broad and potent serologic activity against the virus, revealed that bNAbs target several different conserved epitopes on the HIV-1 Envelope spike protein (Env) using multiple mechanisms of binding (Burton and Hangartner, 2016). The target epitopes of many bNAbs are unusual because they combine host-derived glycans with protein components of Env. Longitudinal cohort and structural studies demonstrated that bNAb maturation mediated by somatic hypermutation (Wei et al., 2003; Liao et al., 2013; Bonsignori et alı, 2017; Bonsignori et al., 2016; DoriaRose et al., 2014; Moore et al., 2012; Bhiman et al., 2015) occurs in part to accommodate the host-derived glycans that shield Env (Wei et al., 2003; Liao et al., 2013; Doria-Rose et al., 2014; Moore et al., 2012; Bhiman et al., 2015; Kong et al., 2013; Garces et al., 2014). 
One of these epitopes, is the V3-glycan supersite, an oligomannose patch around the V3 base of Env and the potential N-linked glycosylation site at position 332 of the Env gp120 subunit (Kong et al., 2013). bNAbs to this site are among the most potent anti HIV-1 antibodies isolated to date and have considerable breadth, moreover, they are among the most frequently elicited upon natural infection with HIV-1 in humans (Walker et al., 2010).

A number of structural studies have shown that the family of V3-glycan bNAbs is highly diverse. They target the GDIR motif of Env using multiple angles of approach and therefore accommodate different surrounding glycans (Kong et al., 2013; Mouquet et al., 2012; Walker et al., 2011a). V3glycan bNAbs use a diverse group of heavy and light chain immunoglobulin genes and only some require the trimeric form of Env for binding (Longo et al., 2016).

BNAbs to this site such as BG18 lack some of the rare features observed in other potent bNAbs, for instance the presence of insertions or deletions that are difficult to induce by vaccination (Freund et al., 2017).

Therefore, the V3-glycan supersite is a good candidate epitope for anti HIV-1 vaccine design purposes.

The observation that bNAbs arise during natural infection in humans (Binley et al., 2008; DoriaRose et alı, 2009; Li et alı, 2009; Sather et al., 2009; Simek et al., 2009; Gray et al., 2011; Hraber et al., 2014; Rusert et al., 2016), and that they can block SHIV infection in macaques (Eichberg et al., 1992; Emini et al., 1992; Mascola et al., 1999; Mascola et al., 2000; Shibata et al., 1999; Baba et al., 2000; Parren et al., 2001; Hessell et al., 2009a; Hessell et al., 2009b; Hessell et al., 2010; Moldt et al., 2012), suggests that a vaccine that elicits such antibodies would be protective.

However, with the exception of experiments performed in genetically engineered mice (Dosenovic et al., 2015; Escolano et al., 2016; Saunders et al., 2019), all efforts to induce anti HIV-1 bNAbs by vaccination have produced only sporadic or less than optimal antibody responses with little or no protective activity against heterologous viral strains (Xu et al., 2018; Saunders et al., 2017). More importantly, it remains unclear which animal model is most relevant to test candidate vaccines.

Because macaque $\mathrm{CD}^{+}{ }^{+} \mathrm{T}$ cells are resistant to HIV-1, SIV/HIV chimeric viruses (SHIVs), carrying the HIV-1 Env, were constructed to target and replicate efficiently in monkey CD4 ${ }^{+} \mathrm{T}_{\text {lymphocytes in }}$ vivo. An intrinsic property of HIV-1 is its replicative vigor and genetic variability in infected persons, both of which confer the capacity to escape immunologic and pharmacologic pressure. Unfortunately, most currently available SHIV challenge viruses do not possess this phenotype and are unable to resist immunologic or CART pressure. This deficiency results in suppressed SHIV replication in many of the inoculated animals and their failure to develop clinical immunodeficiency. In contrast, molecularly cloned SHIV $\mathrm{AD8-EO}$ possesses many of the properties intrinsic to HIV-1. It is R5 tropic, produces sustained levels of plasma viremia in inoculated macaques, exhibits a Tier two neutralization sensitivity phenotype, generates resistant variants in bNAb and ART-treated animals, and causes irreversible depletions of $\mathrm{CD}^{+}{ }^{+} \mathrm{T}$ cells in infected monkeys (Shingai et al., 2013; Gautam et al., 2012; Nishimura et al., 2010; Shingai et al., 2012). SHIV AD8-EO inoculation of macaques invariably leads to symptomatic immunodeficiency associated with opportunistic infections and a fatal clinical outcome in untreated animals. As is the case for some HIV-1 infected individuals, a few SHIV AD8EO-infected monkeys develop neutralizing antibodies against some heterologous clade $A, B$, and $C$ HIV-1 strains (Walker et al., 2011b), including one macaque (CE8J) that exhibited the phenotype observed for HIV-1-infected human elite neutralizers (Walker et al., 2011b). The capacity to generate broadly neutralizing activity persisted throughout the 2 year infection of animal CE8J. This monkey ultimately succumbed to immunodeficiency, and was euthanized 117 weeks post-infection. Plasma mapping studies revealed that neutralizing activity of CE8J macaque exclusively targeted the glycan patch associated with the variable 3 (V3) loop on HIV-1 Env, which is in agreement with studies of emerging viral variants in this macaque that presented substitutions of critical amino acids in the $\mathrm{V} 3$ region (Sadjadpour et al., 2013).

Here, we report on the cloning and molecular characterization of a V3-glycan bNAb produced in this elite neutralizing non-human primate, its structure bound to an HIV-1 Env trimer, and the implications for development of vaccines targeting the V3-glycan patch. 


\section{Results}

\section{Isolation of single Env-specific B cells from a $\mathrm{SHIV}_{\mathrm{ADB} \text {-infected macaque }}$}

To isolate bNAbs from macaque CE8J, we purified germinal center (GC) B cells that bound to YU2 gp140 fold-on trimer (YU2) and BG505 SOSIP.664 trimer (BG505), but not to a control antigen, from lymph nodes collected at the time of necropsy, 115 weeks post-SHIV $\mathrm{AD}_{\mathrm{A} 8}$ infection (Figure 1A and Figure 1-figure supplement 1A).

Immunoglobulin heavy chain (IgH) and light chains Lambda (IgL) and Kappa (IgK)-encoding mRNAs were amplified from the isolated Env-specific B cells by PCR using a set of primers

A

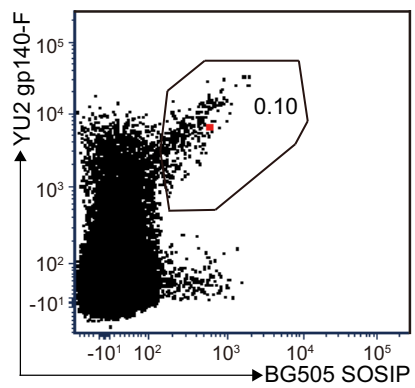

$\mathrm{B}$

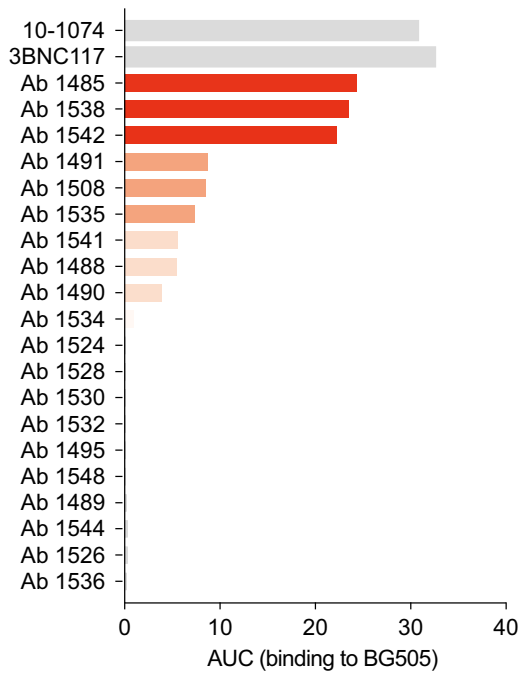

D
C

\begin{tabular}{|c|c|c|c|c|c|c|c|c|}
\hline & Virus ID & Ab1485 & $10-1074$ & PGT121 & 354BG18 & PGT128 & PGT135 & \\
\hline \multirow{8}{*}{ Clade A } & BG505_T332N & 0.015 & ND & ND & ND & ND & ND & \\
\hline & 92RW020 & 0.001 & 0.002 & 0.002 & ND & 0.004 & 0.032 & \\
\hline & Q23_17 & 0.004 & 0.005 & 0.003 & 0.006 & 0.009 & 41.623 & \\
\hline & Q769̄_D22 & $>25$ & $>10$ & $>10$ & $>30$ & $>25$ & $>50$ & \\
\hline & Q461_E2 & $>25$ & $>10$ & $>10$ & $>30$ & $>25$ & $>50$ & \\
\hline & Q842_D12 & $>25$ & $>10$ & 0.011 & 13.986 & 0.013 & $>50$ & \\
\hline & 0260_V5_C36 & $>25$ & 0.164 & 0.046 & ND & 0.042 & 0.792 & \\
\hline & $191955 \_\bar{A} 11$ & $>25$ & $>10$ & $>10$ & $>30$ & 14.2 & $>50$ & \\
\hline \multirow{8}{*}{ Clade B } & JRCSF & 0.308 & 0.004 & 0.039 & ND & 0.005 & 0.069 & \\
\hline & 6535_3 & 0.05 & 0.012 & 0.003 & 0.001 & 0.007 & $>50$ & \\
\hline & TRO_11 & 0.029 & 0.013 & 0.007 & 0.001 & 0.016 & 0.03 & \\
\hline & AC10_29 & 0.001 & 0.02 & 0.026 & 0.001 & 0.009 & $>50$ & \\
\hline & RHPA4259_7 & 0.024 & 0.017 & 0.014 & $>30$ & 0.026 & $>50$ & \\
\hline & QH0692 - & 0.172 & 0.182 & 0.668 & 0.013 & 0.03 & $>50$ & \\
\hline & THRO4156 & $>25$ & $>10$ & $>10$ & $>30$ & $>25$ & $>50$ & \\
\hline & WITO4160_33 & $>25$ & 0.206 & 0.497 & 0.018 & $>25$ & 5.841 & \\
\hline \multirow{7}{*}{ Clade C } & DU422 & 0.052 & 0.048 & 0.052 & 0.009 & 0.064 & $>50$ & \\
\hline & DU156_12 & 0.025 & 0.014 & 0.005 & 0.003 & 0.02 & 20.378 & \\
\hline & ZM249_1 & 19.46 & $>10$ & $>10$ & $>30$ & 25.635 & $>50$ & \\
\hline & ZM197_7 & $>25$ & $>10$ & $>10$ & $>30$ & $>10$ & $>50$ & \\
\hline & ZM109_4 & $>25$ & $>10$ & 10.238 & $>30$ & $>10$ & $>50$ & \\
\hline & ZM135_10A & $>25$ & 0.065 & 0.924 & 0.029 & 30 & $>50$ & \\
\hline & CE1176_A3 & 0.033 & 0.018 & 0.017 & 0.004 & 0.012 & 25.598 & \\
\hline \multirow{2}{*}{ Clade BC } & CNE17 & $>25$ & 1.986 & 10.09 & 0.02 & 0.327 & $>50$ & \\
\hline & CNE19 & $>25$ & 0.042 & 0.01 & $>30$ & $>25$ & 0.008 & \\
\hline \multirow{2}{*}{ Clade D } & 3016_V5_C45 & $>25$ & $>10$ & $>10$ & $>30$ & $>25$ & $>50$ & \\
\hline & 231965_-̄ 1 & $>25$ & 10 & $>10$ & $>30$ & $>25$ & $>50$ & \\
\hline Clade ACD & 0815_V3_C3 & 0.016 & 0.023 & 0.021 & 0.16 & 0.019 & $>50$ & \\
\hline Clade CD & 3301_V1_C24 & $>25$ & 0.011 & 0.01 & 0.025 & 0.083 & $>50$ & \\
\hline \multirow{4}{*}{ Clade G } & X1193_C1 & $>25$ & 0.084 & 0.023 & 0.005 & 0.006 & 0.017 & \\
\hline & X2088_9 & $>25$ & 0.003 & 0.004 & 0.004 & $>25$ & 0.007 & \\
\hline & P0402_C2_11 & 0.009 & 0.007 & 0.008 & 0.005 & 0.007 & $>50$ & \\
\hline & P1981_C5_3 & 0.02 & 0.003 & 0.002 & 0.006 & 0.015 & $>50$ & \\
\hline \multirow{4}{*}{ Clade AG } & T250_4 & 0.124 & 0.001 & 0.001 & 0.001 & 0.002 & $>50$ & \\
\hline & T257_31 & $>25$ & $>10$ & $>10$ & $>30$ & $>25$ & $>50$ & \\
\hline & $928 \_28$ & $>25$ & 0.761 & 35.724 & 0.761 & $>25$ & $>50$ & \\
\hline & T25 $\overline{5} \_34$ & $>25$ & 0.38 & 8.868 & $>30$ & $>25$ & $>50$ & \\
\hline \multirow{5}{*}{ Clade AE } & C1080_C3 & $>25$ & $>10$ & $>10$ & 5.369 & 0.135 & $>50$ & \\
\hline & C2101_C1 & $>25$ & $>10$ & $>10$ & $>30$ & 0.005 & ND & \\
\hline & C4118_9 & $>25$ & $>10$ & $>10$ & $>30$ & $>25$ & $>50$ & IC50 $\mu \mathrm{g} / \mathrm{ml}$ \\
\hline & R1166_C1 & $>25$ & $>10$ & $>10$ & $>30$ & $>25$ & $>50$ & $<1$ \\
\hline & R3265_C6 & $>25$ & $>10$ & $>10$ & $>30$ & $>25$ & $>50$ & $1-100$ \\
\hline
\end{tabular}

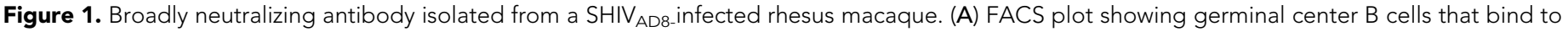
YU2 gp140-F and BG505 SOSIP from a lymph node collected from macaque CE8J at week 115 after SHIV $\mathrm{ADB}_{8}$ infection. The gate shows the sorting window. The B cell carrying the isolated bNAb (Ab1485) is highlighted in red. (B) Graph shows the binding of several monoclonal antibodies isolated from macaque CE8J to BG505 SOSIP (Antibodies were tested for binding to BG505 two or three times. Graph shows data from a representative ELISA). Data is shown as area under the ELISA curve (AUC). (C and D) Table shows the neutralization activity of Ab1485 and other human V3-glycan bNAbs determined in TZM-bl assays against a panel of 42 multi clade tier 1B and tier two pseudoviruses (C) and replication-competent SHIV $\mathrm{ADB}_{\text {(D). }}$ The online version of this article includes the following source data and figure supplement(s) for figure 1:

Source data 1. Macaque antibody sequences.

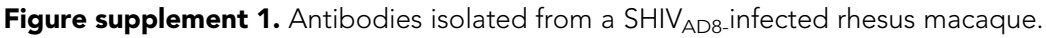


specifically designed to amplify a diverse set of macaque genes (Escolano et alo, 2019). Paired IgH and $\mathrm{IgL} / \mathrm{lgK}$ sequences were obtained for 90 antibodies. Among the 90 antibodies, we found two expanded B cell clones (Figure 1-figure supplement 1B). Sequence analysis revealed that IgH, IgL and IgK genes were somatically hypermutated (averages of 11.8, 8.5, and 4.1 average nucleotide mutations, respectively) (Figure 1-figure supplement 1C). The average length of the complementarity determining region 3 of the heavy chain (CDRH3) was 15.3 amino acids, and 30 of the antibodies had CDRH3s of 18 or more amino acids (Figure 1-figure supplement 1D).

\section{Ab1485 isolated from macaque CE8J is potently neutralizing}

We produced 67 of the 90 monoclonal antibodies and tested them for binding in ELISA to BG505, one of the Env baits that we used to isolate Env-binding B cells. Several antibodies showed detectable binding to BG505, with Ab1485 showing the highest-level binding (Figure 1B). BG505.664 has previously been reported to bind to human bNAbs and show reduced binding to non-neutralizing antibodies (Sanders et al., 2013), thus the three best binders to BG505 were evaluated for neutralizing activity in TZM-bl assays (Montefiori, 2005) against a screening panel of 7 HIV-1 pseudoviruses. Only Ab1485 showed potent and broad activity against this panel (Figure 1-figure supplement 1E) that could explain the activity previously detected in the plasma of macaque CE8J (Walker et al., 2011b). To further evaluate the neutralization potency and breadth of Ab1485, we tested it in TZM-bl assays against a panel of 42 pseudoviruses covering nine different HIV-1 clades and compared its activity to the activity reported for human V3-glycan bNAbs (Figure 1C). Ab1485 neutralized 16 of the isolates in the 42-virus panel with a mean $I_{50}$ of $0.055 \mu \mathrm{g} / \mathrm{mL}$ (Figure 1C), and it was also a potent neutralizer of a replication-competent SHIV (SHIV AD8, $I_{50}=0.028 \mu \mathrm{g} / \mathrm{mL}$, Figure 1D). Ab1485 showed broader activity against this panel of pseudoviruses than the human V3-glycan bNAb PGT135, which neutralizes seven isolates with a mean $\mathrm{IC}_{50}$ of $0.14 \mu \mathrm{g} / \mathrm{mL}$, but lower breadth than 10-1074 (25 isolates with a mean $\mathrm{IC}_{50}$ of $0.16 \mu \mathrm{g} / \mathrm{mL}$ ), PGT121 (23 isolates with a mean $\mathrm{IC}_{50}$ of $0.1 \mu \mathrm{g} / \mathrm{mL}$ ), 354BG18 (19 isolates with a mean $\mathrm{IC}_{50}$ of $0.06 \mu \mathrm{g} / \mathrm{mL}$ ) and PGT128 (22 isolates with a mean IC 50 of $0.04 \mu \mathrm{g} / \mathrm{mL}$ ). The mean IC $\mathrm{C}_{50}$ of Ab1485 against the 14 pseudoviruses for which there is available neutralization data for all these human bNAbs is identical to the mean IC 50 of PGT121, $0.06 \mu \mathrm{g} / \mathrm{mL}$, and significantly lower than the mean IC 50 of PGT13, 17.5 $\mu \mathrm{g} / \mathrm{mL}$. We conclude that Ab1485 is a potent neutralizer with limited breadth compared to some of the human bNAbs reported to date (Sok and Burton, 2018).

\section{Mapping the Ab1485 epitope on HIV-1 Env}

Ab1485 combines the germline V-gene segments VH4_2M and VL124_30 and is highly mutated (33 and 25 nucleotide mutations in the $\mathrm{VH}$ and $\mathrm{VL}$ genes respectively). It has a 20-residue CDRH3 (Figure 2A). We did not find any other family members of Ab1485 when analyzing the LN biopsy collected from macaque CE8J at the time of necropsy (week 115 after SHIV $\mathrm{AD}_{\mathrm{A} 8}$ challenge). In an attempt to find other clonal relatives of Ab1485, and in the absence of available LN biopsies at earlier time points after $\mathrm{SHIV}_{\mathrm{AD} 8}$, we aimed to isolate Env-specific $B$ cells from a PBMC sample collected at week 38 after viral infection using RC1 and BG505 as baits, however, this approach did not yield any $B$ cells to analyze (Figure 1-figure supplement 1F). To characterize the target epitope of Ab1485, we performed competition ELISAs using the bNAbs 10-1074, 3BNC117, 8ANC195, PG9, VRC34 that target the V3-glycan patch, the CD4-binding site, the gp120-gp41 interface, the apex and the fusion peptide of Env, respectively (Mouquet et al., 2012; Scheid et al., 2011; Walker et al., 2009; Kong et al., 2016). Binding of these antibodies was self-inhibitory and in addition, 3BNC117 was partially inhibited by the gp120-gp41 interface bNAb 8ANC195 (Scheid et al., 2011; Scharf et al., 2014; Scharf et al., 2015), and vice versa. The binding of Ab1485 to BG505 was inhibited by the V3-glycan bNAb 10-1074 but not by any of the other human bNAbs (Figure 2B).

To further map the antibody target site, we performed neutralization assays using a series of HIV$1_{\mathrm{JRCSF}}$ mutants (Escolano et alo, 2019). The neutralizing activity of Ab1485 was dependent on the potential $\mathrm{N}$-linked glycosylation sites at $\mathrm{N} 332_{\mathrm{gp} 120}$ and $\mathrm{N} 156_{\mathrm{gp} 120}$, but unaffected by mutations that interfere with the binding of human bNAbs to the interface (N611D), the CD4-binding site (T278A+ A281T), the V1V2 apex (N160K), the MPER (F673L) or the fusion peptide (N88Q) (Figure 2C). In 
A

\begin{tabular}{cccccccc} 
mAb & VH gene & nt mut & CDRH3 & Length & VL gene & nt mut & CDRL3 \\
\hline Ab1485 & IGHV4_2M & 33 & VRGPNHWEYFDSGNNEYFEF & 20 & IGLV124_30 & 25 & QSYDSGLRSYI
\end{tabular}

$\mathrm{B}$
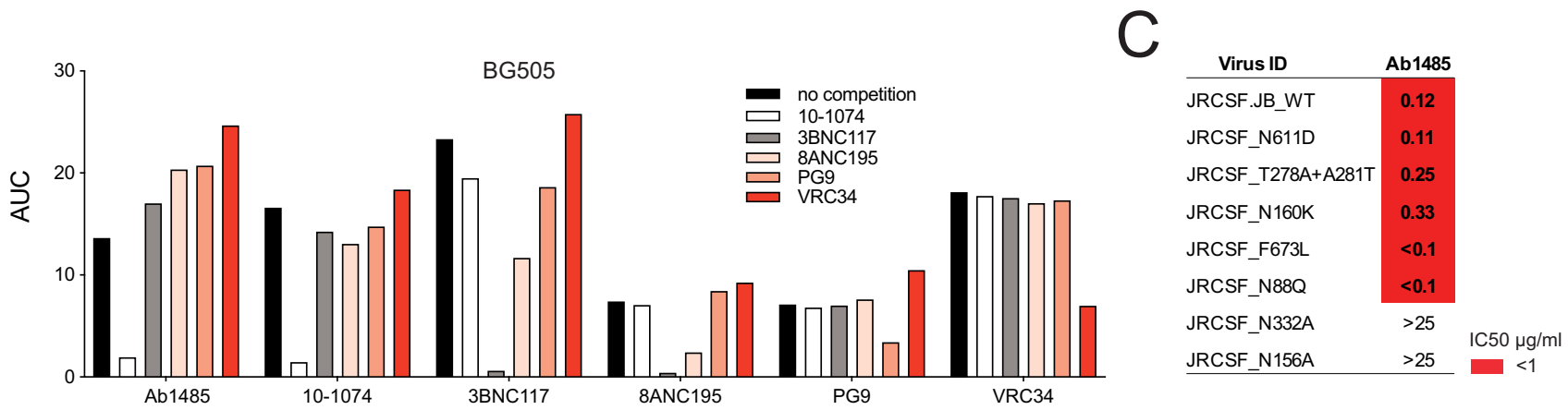

Figure 2. Mapping of Ab1485 binding to Env. (A) Description of Ab1485. (B) Representative ELISA graph showing binding of Ab1485 to BG505 in competition with antibodies that target the V3-glycan epitope (10-1074), the CD4- binding site (3BNC117), the gp120-gp41 interface (8ANC195), the apex (PG9) or the fusion peptide (VRC34) and in the absence of a competing antibody $(n=3)$. (C) Table shows the neutralization activity of Ab1485 determined in TZM-bl assays against a JRCSF pseudovirus and a series of JRCSF mutants that affect the binding of human bNAbs to the interface (N611D), the CD4-binding site (T278A+ A281T), the apex (N160K), the MPER (F673L), and the fusion peptide (N88Q).

conclusion, the competition ELISA and neutralization results suggested that Ab1485 targets the V3glycan patch in Env.

\section{Cryo-EM structure of Ab1485 in complex with BG505}

To elucidate the molecular details of Env recognition by Ab1485, we determined a $3.5 \AA$ cryo-EM structure of Ab1485 in complex with the BG505 SOSIP.664 trimer and the gp120-gp41 interface targeting antibody, 8ANC195 (Scharf et al., 2014; Scharf et al., 2015; Figure 3A, Figure 1-source data 1-table 1 and Figure 3-figure supplement 1). The structure of the Ab1485-Env complex revealed recognition of an epitope focused on the N332 gp120 glycan, the gp120 GDIR peptide motif,

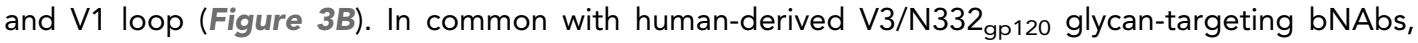
Ab1485's primary interaction was with the N332 ${ }_{\text {gp } 120}$ glycan $\left(\mathrm{Man}_{6} \mathrm{GlcNAc}_{2}\right)$, which interfaces almost entirely with the CDRH3 loop (Figure 3C) ( $400 \AA^{2}$ antibody buried surface area (BSA)). In addition to the N332 gp120 glycan, Ab1485 makes secondary contacts with the N156 gp 120 glycan ( $275 \AA^{2}$ antibody BSA), which frames Ab1485's VH domain at the gp120 V3 epitope, rationalizing the observed loss in neutralization activity when tested against the JRCSF $\triangle \mathrm{N} 156_{\mathrm{gp} 120}$ glycan virus (Figure $2 \mathrm{C}$ ) and consistent with faster dissociation kinetics observed in surface plasmon resonance (SPR) binding experiments that demonstrated a faster dissociation rate for a SOSIP that lacks the N156 gp120 glycan (RC1) compared to a SOSIP that contains the N156 $6_{\mathrm{gp} 120}$ potential $\mathrm{N}$-linked glycosylation site (BG505) (Figure 3-figure supplement 2A-C).

Despite sharing a common interaction with the N332 gp120 glycan, numerous studies have demonstrated that the V3-targeting bNAbs can adopt different binding orientations when targeting the N332 gp120 glycan supersite (Kong et al., 2013; Freund et al., 2017; Pancera et al., 2014). When compared to the poses of human-derived bNAbs (Figure 3D-F) and V3-targeting antibodies elicited in rabbits or rhesus macaques by vaccination or $\mathrm{SHIV}_{\mathrm{BG} 505}$ challenge (Figure 3-figure supplement 2D), Ab1485 adopts a Env-binding orientation in a manner most closely related to PGT128, which

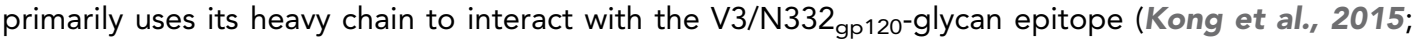
Figure 3D-F). However, in contrast to PGT128, Ab1485 lacks any V-gene insertions or deletions and 


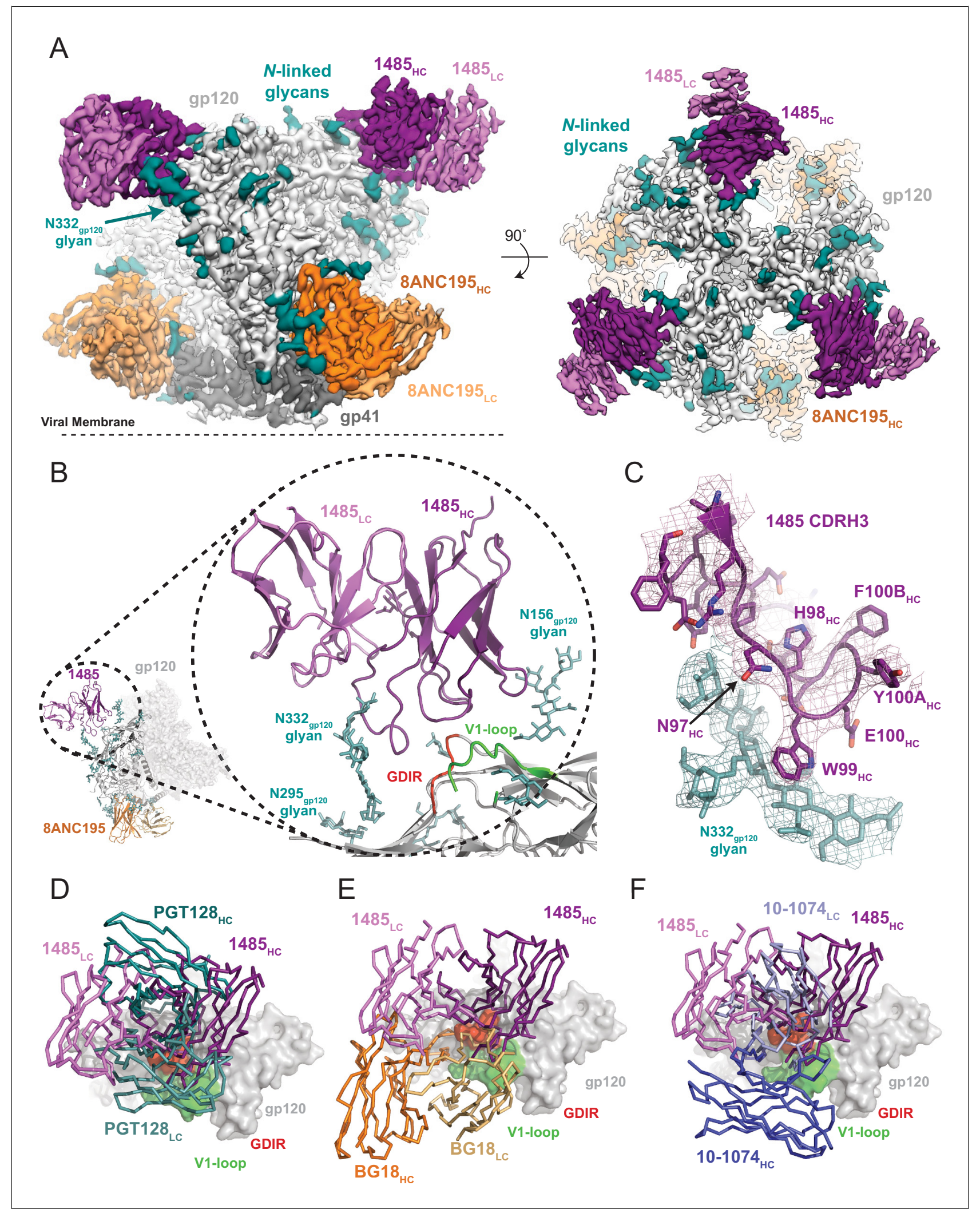

Figure 3. Cryo-EM reconstruction of the Ab1485-BG505 complex reveals a distinct Env-binding orientation relative to human bNAbs. (A) Cryo-EM map of the BG505 SOSIP.664 trimer bound to three Ab1485 (purple shades) and three 8ANC195 (orange shades) Fabs. Densities for glycans are colored in dark teal. (B) Cartoon depiction of the modeled complex with a close-up view of the Ab1485 Fab - gp120 interface. Conserved regions of the V3epitope are highlighted. (C) Cartoon and stick representation of the Ab1485 CDRH3 recognition of the N332 gp120-glycan. Reconstructed cryo-EM map Figure 3 continued on next page 
Figure 3 continued

shown as a mesh, contoured at three sigma. (D-F) Comparison of Ab1485's (purple) Env-binding orientation to (D) PGT128 (teal, PDB 5ACO), (E) BG18 (orange, PDB 6CH7), and (F) 10-1074 (blue, PDB 5T3Z).

The online version of this article includes the following figure supplement(s) for figure 3 :

Figure supplement 1. Cryo-EM data processing and validation.

Figure supplement 2. Binding assays and structural comparison to V1//V3 antibodies raised in animals.

its orientation is rotated $\sim 90^{\circ}$ relative to $\mathrm{PGT128}$, resulting in a unique Env-binding orientation that shifts interactions away from the $\mathrm{N} 301_{\mathrm{gp} 120} \mathrm{~N}$-glycan and towards the N156 $6_{\mathrm{gp} 120}$ glycan, and moves the light chain outside of the underlying V3-epitope (Figure 3 and Figure 4A-C). Thus, interactions with the $\mathrm{N}$-linked glycans and gp120 peptide components are almost exclusively mediated by the Ab1485 heavy chain (Figure 4A, B; $1255 \AA^{2}$ vs $65 \AA^{2}$ buried surface areas for $H C$ and LC components of Ab1485 paratope, respectively). This observation suggests that Ab1485 may not be restricted by light chain pairing or require the consensus light chain sequence motifs commonly observed in

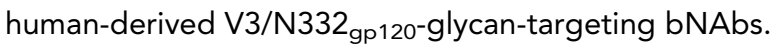

Closer examination of the Ab1485 epitope revealed that all three heavy chain CDR loops contact the ${ }_{324} \mathrm{GDIR}_{327}$ gp120 peptide motif at the base of the V3-loop, which contrasts interactions by both heavy and light chain CDR loops observed in 10-1074/PGT121-like and BG18 bNAbs (Gristick et al., 2016; Barnes et al., 2018; Figure 4B,D). The primary molecular contacts are with $\mathrm{CDRH} 1$ residues $\mathrm{R}_{3} \mathrm{HC}_{\mathrm{HC}} \mathrm{S} 31_{\mathrm{HC}}$, and $\mathrm{N} 32_{\mathrm{HC}}$, which form potential hydrogen bonds with backbone and sidechain atoms from residues $\mathrm{G} 324_{\mathrm{gp} 120}$ and D325 $5_{\mathrm{gp} 120}$ (Figure 4E). Interestingly, these CDRH1 residues mimic interactions made by CDRL1/L3 residues in PGT121/101074-like bNAbs with Env, providing evidence for a convergent chemical mechanism of interactions with the gp120 GDIR motif, as previously shown for BG18 (Barnes et al., 2018). Moreover, Ab1485 residue R30 ${ }_{\mathrm{HC}}$ forms secondary interactions with $\mathrm{V} 1$ loop residues $\mathrm{V} 134_{\mathrm{gp} 120}$ and $\mathrm{T} 135_{\mathrm{gp} 120}$, resembling similar argininegp120 V1-loop interactions observed in 10-1074, BG18, and PGT128 (Kong et al., 2015; Gristick et al., 2016; Barnes et al., 2018).

A common interaction seen in the PGT121/101074-like, BG18, and PGT128 bNAbs involves the formation of a salt bridge between R327 $7_{\mathrm{gp} 120}$ and an either a glutamate or aspartate in CDRH3 (12, 58). The Ab1485-BG505 structure reveals an alternate binding mode that involves the guanidinium moiety of R327 $7_{\text {gp } 120}$ forming cation-pi stacking interactions with W99 $_{\mathrm{HC}}$ at the tip of the Ab1485's $\mathrm{CDRH} 3$, while also participating in hydrogen bonding with the backbone carbonyl group (Figure 4E). While $\mathrm{CDRH} 3$ residue $\mathrm{E} 100_{\mathrm{HC}}$ could potentially adopt a conformation that would promote salt- bridge formation with $\mathrm{R} 327_{\mathrm{gp} 120}$, this residue is pointed outward and within $\mathrm{H}$-bonding

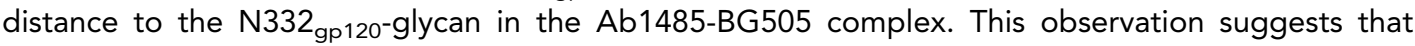
salt-bridge formation between $\mathrm{R} 327_{\mathrm{gp} 120}$ and an acidic $\mathrm{CDRH} 3$ residue found in $\mathrm{V} 3$-targeting bNAbs may not be as critical to targeting the V3/N332gp120-glycan epitope.

\section{Ab1485 protects from infection by SHIV $_{\text {ADs }}$ in rhesus macaques}

To determine whether Ab1485 can protect against SHIV $_{\mathrm{AD} 8}$ infection in macaques, we expressed a fully macaque lgG, including $F c$ region substitutions that increase half-life through rescue by increased FcRn recycling (Ab1485-LS) (Zalevsky et al., 2010). Ab1485 was not polyreactive, as shown by ELISAs against a series of antigens (Figure 5-figure supplement 1A) and Ab1485-LS had a half-life of 2.67 days in transgenic human FcRn mice (Roopenian et al., 2003; Figure 5-figure supplement 1B). The protective efficacy of Ab1485-macaque-LS was assessed in rhesus macaques that received a single high dose of $\mathrm{SHIV}_{\mathrm{AD} 8}$ intrarectally (1000 TCID50) one day after a single intravenous infusion of $\mathrm{Ab} 1485$ at $10 \mathrm{mg} / \mathrm{kg}$ body weight (Figure 5A). Two historical control monkeys (Yamamoto, 2015) receiving no mAb, rapidly became infected, generating peak levels of plasma viremia on day 14 post-challenge. In contrast, the four macaques receiving Ab1485 remained uninfected throughout a 25-week observation period (Figure 5B). Neutralizing antibody titers persisted in the peripheral blood for at least 50 days after the virus challenge (Figure $5 \mathrm{C}$ ). We conclude that Ab1485-macaque-LS protects macaques from high dose intrarectal SHIV AD8 $_{\text {infection. }}$ 


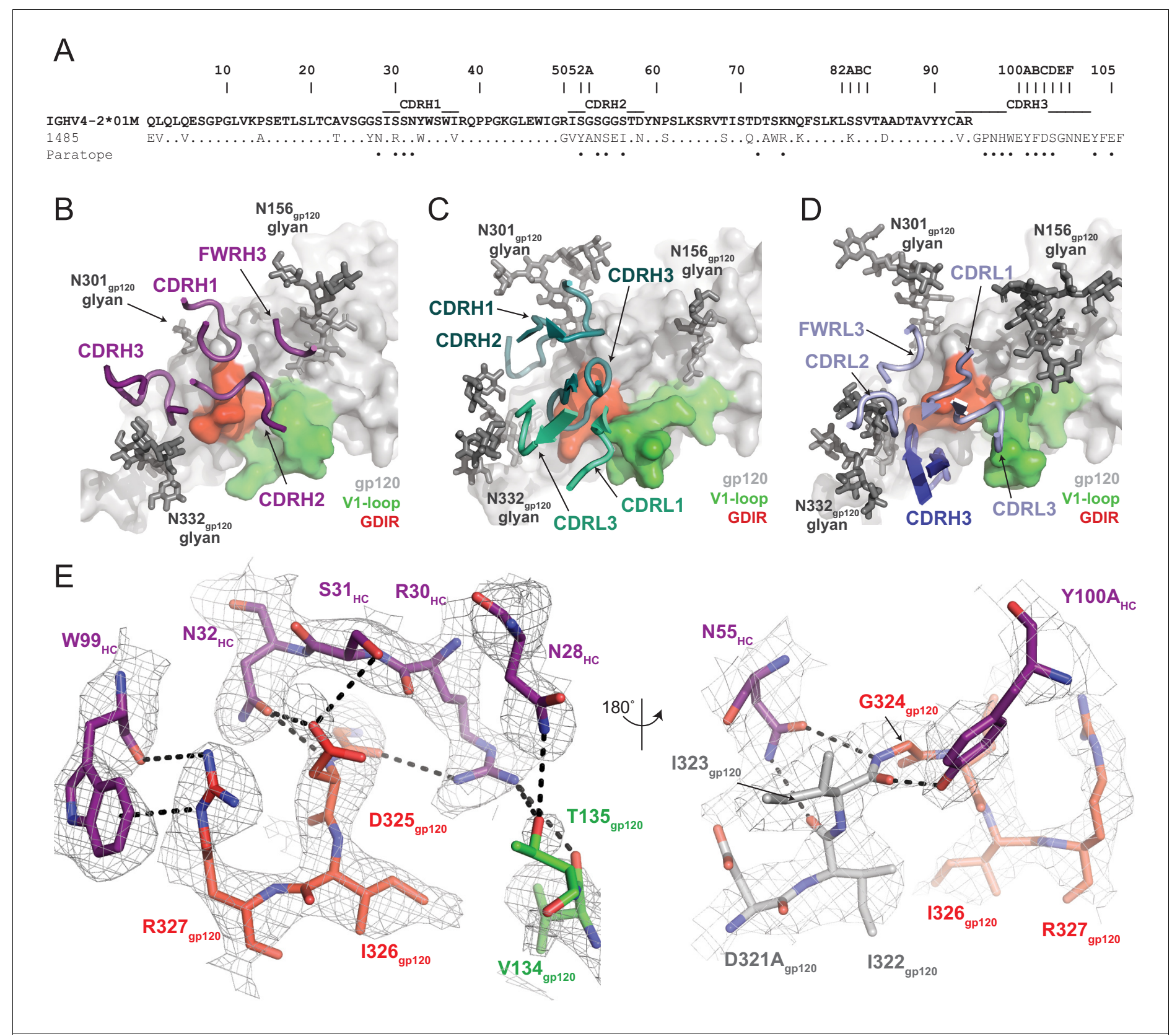

Figure 4. Molecular details of Ab1485-gp120 interactions. (A) Sequence alignment of mature Ab1485 heavy chain with germline VH4-2*01M. Paratope residues are highlighted. (B-D) Comparison of the paratope CDR loops and FWRs involved in epitope recognition for (B) Ab1485, (C) PGT128, and (D) 10-1074. (E) Stick representation of interactions between Ab1485 (purple) and either the GDIR peptide motif (red) or V1 loop (green). Potential H-bonds defined are shown as black dashes.

\section{Discussion}

Indian-origin rhesus macaques infected with SHIV are an important model for evaluating HIV-1 prevention and therapy strategies. Macaques can also potentially be used to evaluate humoral immune responses to candidate HIV-1 vaccines, but whether macaques produce human-like bNAbs has not been evaluated. We have examined the antibody response of macaque CE8J who developed broad

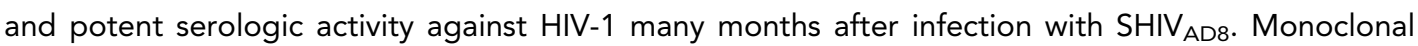


A

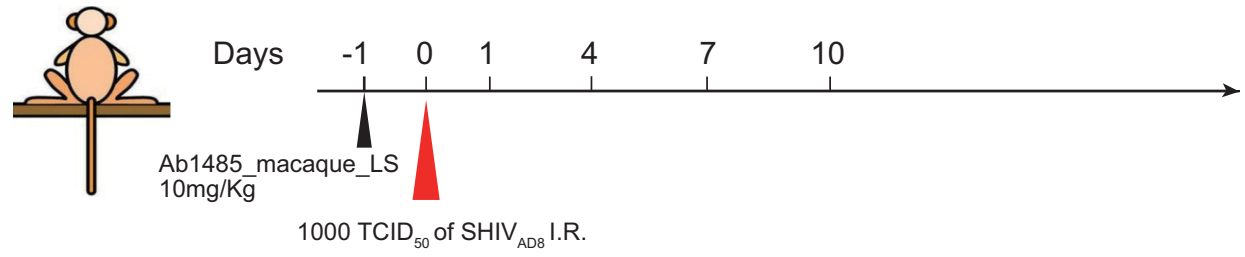

B

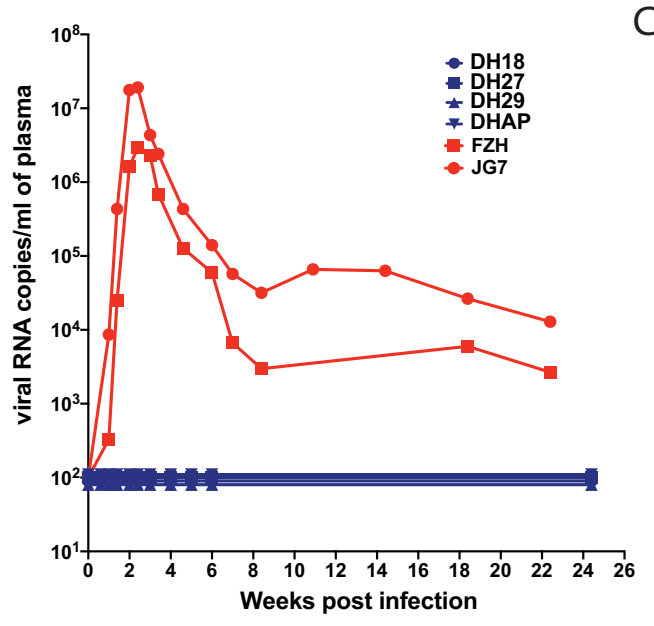

C

\begin{tabular}{l|cccc} 
& \multicolumn{4}{c}{ ID50 reciprocal dilutions } \\
\cline { 2 - 5 } $\begin{array}{c}\text { Days post } \\
\text { Ab1485 }\end{array}$ & DH18 & DH27 & DH29 & DHAP \\
\hline Day 1 & 29112 & 28917 & 19502 & 22057 \\
Day 5 & 7953 & 9460 & 6994 & 6190 \\
Day 8 & 5876 & 6738 & 2124 & 3694 \\
Day 11 & 3354 & 4946 & 1147 & 1396 \\
Day 15 & 1501 & 1934 & 495 & 826 \\
Day 22 & 659 & 1065 & 153 & 345 \\
Day 29 & 456 & 564 & 110 & 196 \\
Day 36 & 229 & 335 & 96 & 132 \\
Day 43 & 106 & 116 & 37 & 73 \\
Day 50 & 71 & 90 & 22 & 44 \\
\hline
\end{tabular}

Figure 5. Ab1485 protects macaques against a high dose intrarectal challenge with $\mathrm{SHIV}_{\mathrm{AD} 8}$. (A) Diagrammatic representation of the regimen used to assess the protective efficacy of Ab1485. Macaques were administered with Ab1485 at a dose of $10 \mathrm{mg} \mathrm{kg}^{-1}$ and challenged one day later with 1000 TCID 50 of SHIV ADs intrarectally (I.R.) (B) Longitudinal analysis of plasma viral loads in two control macaques (FZH and JG7) receiving no $\mathrm{Ab}$ and four macaques (DH18, DH27, DH29, and DHAP) infused with Ab1485 $24 \mathrm{hr}$ prior to SHIV AD8 $_{\text {challenge. (C) Serum }}$ neutralizing antibody titers in macaques receiving $A b 1485$. The $I C_{50}$ titers are color coded: 1:21-99 in green; 1:100-999 in yellow and $\geq 1: 1000$ in red.

The online version of this article includes the following figure supplement(s) for figure 5 :

Figure supplement 1. Characterization of Ab1485.

Ab1485 obtained from single-B-cells purified on the basis of HIV-1 Env-binding by cell sorting neutralized 16 of 42 of the HIV-1 strains tested with $\mathrm{IC}_{50}$ lower than $1 \mu \mathrm{g} . \mathrm{ml}$. Through biochemical and structural analysis, we determined that antibody 1485 targets the V3/N332 gp 120 -glycan epitope and does so in a manner that is similar to the human V3-targeting antibodies. Thus, rhesus macaques develop anti-HIV-1 V3-glycan patch bNAbs that resemble human bNAbs.

As many as $10-20 \%$ of HIV-1 infected humans develop antibodies that can neutralize a number of different HIV-1 strains, but only an elite few (1-2\%) produce potent broadly neutralizing serologic activity (Landais and Moore, 2018). The elite humoral responders typically take 1-3 years to produce bNAbs, which is highly unusual for an antibody response. Single cell antibody cloning revealed that human bNAbs carry large numbers of somatic mutations that are required for their neutralizing activity (Mouquet et alo, 2012; Scheid et al., 2011; Scheid et al., 2009; Xiao et alo, 2009; Muster et alı, 1993; Zhou et al., 2010; Hoot et alı, 2013; Klein et alo, 2013; Sok et al., 2013; Kepler et al., 2014; Bonsignori et al., 2011). This observation led to the proposal that the development of bNAbs required a prolonged series of sequential interactions between the antibody-producing B lymphocytes and virus escape variants to drive antibody maturation (Scheid et al., 2009; Dimitrov, 2010). Elegant prospective studies of virus and antibody evolution supported this concept 
(Liao et alı, 2013; Bonsignori et al., 2017; Doria-Rose et al., 2014; Moore et al., 2012; Bhiman et al., 2015), and sequential immunization experiments reproduced it in knock in mice (Escolano et al., 2016). Monoclonal antibody Ab1485 resembles human bNAbs in many important respects including the high levels of somatic mutation suggesting a requirement for sequential interaction between $B$ cells and the virus to drive bNAb evolution in macaques. This process of virus and antibody co-evolution has been recently shown in macaques in a study by Roark and colleagues (preprint in bioRxiv, Roark et al., 2020). Their work shows that infection with SHIVs bearing the Envs of transmitted founder (T/F) HIV-1 viruses that induced bNAbs in humans, recapitulates key events of the previously reported interplay between HIV-1 and antibodies in the infected individuals. Infection with one of these T/F-SHIVs, SHIV.CH505, induced the development of a lineage of V2-apex bNAbs that shows certain breadth and potency against tier 1 and tier two pseudoviruses. The most mutated member of this lineage, RHA1.V2.01, has comparable frequencies of IgH V(D)J nucleotide mutations to Ab1485 (8.5\% in RHA1.V2.01 vs $8.6 \%$ in Ab1485) and slightly lower mutation frequencies in the IgL (6.2\% in RHA1.V2.01 vs 7.55\% in Ab1485). Regarding the neutralization activity, RHA1.V2.01 and Ab1485 show similar breadth when considering isolates neutralized at $\mathrm{IC}_{50}<1 \mu \mathrm{g} / \mathrm{mL}(30.7 \%$ for RHA1.V2.01 vs 38.1\% for Ab1485) but Ab1485 is more potent against the reported neutralized isolates (mean $\mathrm{IC}_{50}$ of RHA1.V2.01 $=0.214 \mu \mathrm{g} / \mathrm{mL}$ vs mean $\mathrm{IC}_{50}$ of $\mathrm{Ab} 14850.055 \mu \mathrm{g} / \mathrm{mL}$ ).

Monoclonal antibody Ab1485 targets the glycan patch that surrounds the conserved GDIR peptide at the base of the V3 loop, an epitope that is frequently targeted by human bNAbs. Ab1485 resembles PGT128 in that most of the interactions with the V3/N332 gp120-glycan epitope are mediated by heavy chain CDR loops, including conserved interactions with the N332 ${ }_{\text {gp } 120}$ glycan and gp120 GDIR peptide motif. Recent studies in macaques showed that after priming with a designed immunogen that focuses the response to the V3-glycan epitope, antibodies with binding features of V3-glycan-targeting bNAbs can be isolated (Escolano et al., 2019). Whether these early antibodies can mature to develop broad neutralizing activity remains to be determined, but antibodies like Ab1485 may provide a blueprint for achieving such broad and potent activity.

Some of the predicted impediments for Env-binding of germline forms of PGT121/10-1074-like or BG18-like antibodies are related to overcoming unfavorable interactions with the antibody light chain, particularly with the gp120 V1 loop. The unique orientation adopted by Ab1485, which positions the LC away from the V1 loop, may provide an easier path towards antibody maturation. Overall, structural analysis of 1485 provides: (i) evidence that effective bNAbs targeting the V3/ N332 gp120-glycan epitope are not restricted to PGT128, BG18 or 10-1074/PGT121-like binding mechanisms, (ii) critical structural insights towards immunogen design efforts to elicit neutralizing antibodies, including alternative binding modes that do not include light chain interactions, and (iii) evidence that $\mathrm{SHIV}_{\mathrm{AD} 8}$-infected macaques are capable of generating bNAbs that target the V3/ N332 gp120-glycan epitope in a manner similar to human-derived bNAbs, and therefore represent an excellent animal model for developing HIV-1 vaccines targeting this site.

Human bNAbs can protect humanized mice and macaques from HIV-1 and SHIV infections, respectively, when given prophylactically (Eichberg et al., 1992; Emini et al., 1992; Mascola et al., 1999; Mascola et alı, 2000; Shibata et alı, 1999; Baba et alı, 2000; Parren et alı, 2001; Hessell et alı, 2009a; Hessell et al., 2009b; Hessell et al., 2010; Moldt et al., 2012; Pietzsch et al., 2012; Gruell et al., 2013). They can also suppress infection for prolonged periods of time in mice and macaques (Shingai et alı, 2013; Barouch et al., 2013; Nishimura et al., 2017; Horwitz et al., 2013). When administered to Indian-origin rhesus macaques during the acute SHI$\mathrm{V}_{\mathrm{AD} 8}$ infection they induced host CD8+ $\mathrm{T}$ cell-dependent immunity that can suppress infection for 2 to 3 years (Nishimura et al., 2017). However, prolonged administration of these human monoclonal antibodies to macaques has not been possible due to rapid development of macaque anti-human antibody responses. The fully-native macaque Ab1485 will facilitate such therapies and reservoir reduction experiments that require prolonged bNAb administration to macaques.

Finally, the observation that Indian-origin rhesus macaques develop V3-glycan patch bNAbs that resemble human bNAbs is strongly supportive of the use of this model organism to test HIV-1 candidate vaccines that target this epitope. 


\section{Materials and methods}

\section{Key resources table}

\begin{tabular}{|c|c|c|c|c|}
\hline $\begin{array}{l}\text { Reagent type } \\
\text { (species) or } \\
\text { resource }\end{array}$ & Designation & $\begin{array}{l}\text { Source or } \\
\text { reference }\end{array}$ & Identifiers & $\begin{array}{l}\text { Additional } \\
\text { information }\end{array}$ \\
\hline $\begin{array}{l}\text { strain, strain } \\
\text { background } \\
\text { (Mus musculus Female) }\end{array}$ & $\begin{array}{l}\text { B6. Cg-Fcgrt }{ }^{\mathrm{tm} 1 \mathrm{Dcr}} \mathrm{Tg} \text { (CAG- } \\
\text { FCGRT)276Dcr/ } \\
\text { DcrJ mice } \\
\text { (FcRn -/- hFcRn) }\end{array}$ & $\begin{array}{l}\text { The Jackson } \\
\text { Laboratory }\end{array}$ & 004919 & $\begin{array}{l}7-8 \text { weeks } \\
\text { of age }\end{array}$ \\
\hline $\begin{array}{l}\text { cell line } \\
\text { (human) }\end{array}$ & HEK293-6E & $\begin{array}{l}\text { National } \\
\text { Research } \\
\text { Council } \\
\text { of Canada }\end{array}$ & RRID:CVCL_HF2O & \\
\hline $\begin{array}{l}\text { Cell line } \\
\text { (human) }\end{array}$ & $\begin{array}{l}\text { Expi293F } \\
\text { cells }\end{array}$ & Invitrogen & A14527 & \\
\hline $\begin{array}{l}\text { cell line } \\
(\mathrm{CHO})\end{array}$ & $\begin{array}{l}\text { CHO Flp- } \\
\text { InTM cells }\end{array}$ & Invitrogen & R75807 & $\begin{array}{l}\text { Chung et al., } 2014 \\
\text { PMID:24767177 }\end{array}$ \\
\hline $\begin{array}{l}\text { Recombinant } \\
\text { protein }\end{array}$ & $\begin{array}{l}\text { Avi-tagged } \\
\text { BG505 SOSIP }\end{array}$ & $\begin{array}{l}\text { Kindly provided } \\
\text { by Dr. Rogier } \\
\text { W. Sanders } \\
\text { and Dr. Marit } \\
\text { van Gils. }\end{array}$ & & $\begin{array}{l}\text { Sok et al., } 2013 \\
\text { PMID:25422458 }\end{array}$ \\
\hline $\begin{array}{l}\text { Recombinant } \\
\text { protein }\end{array}$ & $\begin{array}{l}\text { Avi-tagged YU2- } \\
\text { gp140 fold-on }\end{array}$ & $\begin{array}{l}\text { Kindly } \\
\text { provided } \\
\text { by Dr. R. Wyatt }\end{array}$ & & \\
\hline $\begin{array}{l}\text { Recombinant } \\
\text { protein }\end{array}$ & $\begin{array}{l}\text { Avi-tagged } \\
\text { Hepatitis B } \\
\text { surface antigen }\end{array}$ & $\begin{array}{l}\text { Protein } \\
\text { Specialists }\end{array}$ & hbs-875 & \\
\hline $\begin{array}{l}\text { Recombinant } \\
\text { protein }\end{array}$ & $\begin{array}{l}\text { Avi-tagged } \\
\mathrm{RC} 1\end{array}$ & & & $\begin{array}{l}\text { Escolano et al., } 2019 \\
\text { PMID:31142836 }\end{array}$ \\
\hline $\begin{array}{l}\text { Recombinant } \\
\text { protein }\end{array}$ & $\begin{array}{l}\text { Avi-tagged } \\
\text { RC1_KO }\end{array}$ & & & $\begin{array}{l}\text { Escolano et al., } 2019 \\
\text { PMID:31142836 }\end{array}$ \\
\hline $\begin{array}{l}\text { Recombinant } \\
\text { protein }\end{array}$ & $\begin{array}{l}\text { BG505 } \\
\text { SOSIP.664 } \\
\text { trimer }\end{array}$ & & & $\begin{array}{l}\text { Schoofs et al., } 2019 \\
\text { PMID:31126879 }\end{array}$ \\
\hline $\begin{array}{l}\text { Commercial } \\
\text { assay or kit }\end{array}$ & $\begin{array}{l}\text { Zombie NIR } \\
\text { Fixable Viability } \\
\text { Kit }\end{array}$ & Biolegend & 77184 & $(1: 400)$ \\
\hline $\begin{array}{l}\text { Commercial } \\
\text { assay or kit }\end{array}$ & $\begin{array}{l}\text { TCL lysis } \\
\text { buffer }\end{array}$ & Qiagen & 1031576 & \\
\hline $\begin{array}{l}\text { Commercial } \\
\text { assay or kit }\end{array}$ & RNAClean XP & Beckman Counter & A63987 & \\
\hline antibody & $\begin{array}{l}\text { anti CD3-APC- } \\
\text { eFluor } 780 \\
\text { (mouse } \\
\text { monoclonal) }\end{array}$ & Invitrogen & $47-0037-41$ & $(1: 200)$ \\
\hline antibody & $\begin{array}{l}\text { anti CD14-APC- } \\
\text { eFluor } 780 \\
\text { (mouse } \\
\text { monoclonal) }\end{array}$ & Invitrogen & $47-0149-42$ & $(1: 200)$ \\
\hline antibody & anti CD38 FITC & Stem Cell & $60131 \mathrm{FI}$ & $(1: 200)$ \\
\hline antibody & $\begin{array}{l}\text { anti CD16-APC- } \\
\text { eFluor } 780 \\
\text { (mouse } \\
\text { monoclonal) }\end{array}$ & Invitrogen & $47-0168-41$ & $(1: 200)$ \\
\hline antibody & $\begin{array}{l}\text { anti CD8-APC- } \\
\text { eFluor } 780 \\
\text { (mouse } \\
\text { monoclonal) }\end{array}$ & Invitrogen & $47-0086-42$ & $(1: 200)$ \\
\hline
\end{tabular}

Continued on next page 
Continued

\begin{tabular}{|c|c|c|c|c|}
\hline $\begin{array}{l}\text { Reagent type } \\
\text { (species) or } \\
\text { resource }\end{array}$ & Designation & $\begin{array}{l}\text { Source or } \\
\text { reference }\end{array}$ & Identifiers & $\begin{array}{l}\text { Additional } \\
\text { information }\end{array}$ \\
\hline antibody & $\begin{array}{l}\text { anti CD20-PE-Cy7 } \\
\text { (mouse } \\
\text { monoclonal) }\end{array}$ & $\begin{array}{l}\text { BD } \\
\text { Biosciences }\end{array}$ & 335793 & $(1: 200)$ \\
\hline antibody & $\begin{array}{l}\text { HRP-conjugated } \\
\text { anti-human lgG } \\
(\mathrm{Fc}) \mathrm{CH} 2 \\
\text { Domain antibody } \\
\text { (mouse } \\
\text { monoclonal) }\end{array}$ & Bio-Rad & MCA647P & $(1: 5000)$ \\
\hline $\begin{array}{l}\text { software, } \\
\text { algorithm }\end{array}$ & WinNonlin 6.3 & Certara Software & & \\
\hline $\begin{array}{l}\text { software, } \\
\text { algorithm }\end{array}$ & $\begin{array}{l}\text { MacVector } \\
\text { v.17.0.2 }\end{array}$ & MacVector & & \\
\hline $\begin{array}{l}\text { software, } \\
\text { algorithm }\end{array}$ & $\begin{array}{l}\text { FlowJo } \\
\text { v.10.6.1 }\end{array}$ & Becton Dickinson & & \\
\hline $\begin{array}{l}\text { software, } \\
\text { algorithm }\end{array}$ & FCS EXPRESS & De Novo & & \\
\hline $\begin{array}{l}\text { software, } \\
\text { algorithm }\end{array}$ & $\begin{array}{l}\text { GraphPad } \\
\text { Prism } 7\end{array}$ & GraphPad & & \\
\hline $\begin{array}{l}\text { software, } \\
\text { algorithm }\end{array}$ & SeqlO & Biopython & & \\
\hline $\begin{array}{l}\text { software, } \\
\text { algorithm }\end{array}$ & cutadapt v.2.3 & cutadapt & & \\
\hline $\begin{array}{l}\text { Software, } \\
\text { algorithm }\end{array}$ & $\begin{array}{l}\text { Change-O } \\
\text { toolkit v.0.4.5 }\end{array}$ & & & PMID:26069265 \\
\hline $\begin{array}{l}\text { software, } \\
\text { algorithm }\end{array}$ & SerialEM v3.7 & & RRID:SCR_017293 & $\begin{array}{l}\text { Mastronarde, } 2005 \\
\text { PMID:16182563 }\end{array}$ \\
\hline $\begin{array}{l}\text { software, } \\
\text { algorithm }\end{array}$ & cryoSPARCv2.14 & & RRID:SCR_016501 & $\begin{array}{l}\text { Punjani et al., } 2017 \\
\text { PMID:28165473 }\end{array}$ \\
\hline $\begin{array}{l}\text { software, } \\
\text { algorithm }\end{array}$ & Relion v3.0 & & RRID:SCR_016274 & $\begin{array}{l}\text { Zivanov et al., } 2018 \\
\text { PMID:30412051 }\end{array}$ \\
\hline $\begin{array}{l}\text { software, } \\
\text { algorithm }\end{array}$ & $\begin{array}{l}\text { UCSF Chimera } \\
\text { v1.13 }\end{array}$ & & RRID:SCR_004097 & $\begin{array}{l}\text { Goddard et al., 2007, } \\
\text { PMID:16963278 }\end{array}$ \\
\hline $\begin{array}{l}\text { software, } \\
\text { algorithm }\end{array}$ & Phenix v1.17 & & RRID:SCR_014224 & $\begin{array}{l}\text { Afonine, et al, ACTA D, 2018, } \\
\text { PMID:29872004 }\end{array}$ \\
\hline $\begin{array}{l}\text { software, } \\
\text { algorithm }\end{array}$ & Coot v0.8.9 & & RRID:SCR_014222 & $\begin{array}{l}\text { Emsley et alo, 2010, } \\
\text { PMID:20383002 }\end{array}$ \\
\hline $\begin{array}{l}\text { software, } \\
\text { algorithm }\end{array}$ & $\begin{array}{l}\text { PyMOL } \\
\text { v1.8.2.1 }\end{array}$ & Schrodinger, Inc & RRID:SCR_000305 & $\begin{array}{l}\text { https://pymol. } \\
\text { org/2/ }\end{array}$ \\
\hline $\begin{array}{l}\text { software, } \\
\text { algorithm }\end{array}$ & $\begin{array}{l}\text { Biacore T200 } \\
\text { Evaluation } \\
\text { Software v3.2 }\end{array}$ & Cytiva & & \\
\hline
\end{tabular}

\section{Flow cytometry and single-B-cell sorting}

Frozen lymph node (LN) cell suspensions collected from macaque CE8J at 117 weeks post-infection were thawed and incubated in FACS buffer (1 X Phosphate-buffered saline (PBS), 2\% calf serum, 1 mM EDTA.) with the following anti human antibodies: anti CD3-APC-eFluor 780 (Invitrogen, 470037-41), anti CD14-APC-eFluor 780 (Invitrogen, 47-0149-42), anti CD16-APC-eFluor 780 (Invitrogen, 47-0168-41), anti CD8-APC-eFluor 780 (Invitrogen, 47-0086-42), anti CD20-PE-Cy7 (BD biosciences, 335793), and anti CD38 FITC (Stem Cell, 60131FI) and the Zombie NIR Fixable Viability Kit (Biolegend, 77184). Avi-tagged and biotinylated BG505 SOSIP, YU2-gp140 fold-on, and hepatitis B surface antigen (HBs Ag) (Protein Specialists, hbs-875) conjugated to streptavidin Alexa Fluor 647 (Biolegend, 405237), streptavidin PE (BD biosciences, 554061) and streptavidin BV711(BD 
biosciences, 563262) respectively were added to the antibody mixture and incubated with the LN cells for $30 \mathrm{~min}$. Single CD3 ${ }^{-} \mathrm{CD} 8^{-} \mathrm{CD} 14^{-} \mathrm{CD} 16^{-} \mathrm{CD} 20^{+} \mathrm{CD} 38^{+}$BG505 SOSIP ${ }^{+}$YU2-gp $140^{+}$B cells were sorted into individual wells of a 96-well plates containing $5 \mu$ l of a lysis buffer (Qiagen, 1031576) per well using a FACS Aria III (Becton Dickinson). The sorted cells were stored at $-80^{\circ} \mathrm{C}$ or immediately used for subsequent RNA purification (Escolano et alı, 2019; Wang et al., 2020).

A PBMC sample collected from macaque CE8J at week 38 post-SHIVAD8 infection was thawed and incubated in FACS buffer with the following anti human antibodies: anti CD3-APC-eFluor 780 (Invitrogen, 47-0037-41), anti CD14-APC-eFluor 780 (Invitrogen, 47-0149-42), anti CD16-APC-eFluor 780 (Invitrogen, 47-0168-41), anti CD8-APC-eFluor 780 (Invitrogen, 47-0086-42), and anti CD20-PECy7 (BD biosciences, 335793), and the Zombie NIR Fixable Viability Kit (Biolegend, 77184). Avitagged and biotinylated RC1_KO, RC1, and BG505 SOSIPs conjugated to streptavidin BV605, streptavidin PE and APC, and streptavidin PerCP Cy5.5 respectively were added to the antibody mixture and incubated with the PBMCs for $30 \mathrm{~min}$.

The use of streptavidin tetramers to facilitate the detection of the interaction between the $B$ cells and Env may allow the isolation of B cells that bind Env with low affinity. The binding avidity under these conditions may facilitate the detection of B cell-Env interactions that are not detected by other methods such as ELISAs.

\section{Single-B-cell antibody cloning}

Single cell RNA was purified from individual B cells using magnetic beads (Beckman Counter, RNAClean XP, A63987) and used for cDNA synthesis by reverse transcription (SuperScript III Reverse Transcriptase, Invitrogen, 18080-044, 10,000 U). cDNA was stored at $-20^{\circ} \mathrm{C}$ or used for subsequent amplification of the variable $\mathrm{lgH}$, $\mathrm{lg} \mathrm{L}$, and $\mathrm{lgK}$ genes by nested PCR and SANGER sequencing using the primers and protocol previously described (Escolano et al., 2019).

$\operatorname{lgH}, \lg \mathrm{L}$, and $\lg \mathrm{K} V(\mathrm{D}) \mathrm{J}$ genes were cloned into expression vectors containing the human $\lg \mathrm{G} 1$, IgL, or IgK constant region using sequence and ligation independent cloning (SLIC) as previously described (Escolano et al., 2019; von Boehmer et alı, 2016). Ab1485-macaque-LS was cloned using pre designed gene fragments (IDT).

The primers used to amplify the immunoglobulin genes anneal at the beginning of the framework region one and the end of the $\mathrm{J}$ genes, therefore, this method is likely to introduce point mutations in these regions that may affect the binding properties of the cloned antibodies.

The sorting strategy does not include staining for the antibody isotype, and the primers used to amplify the antibody genes anneal outside the constant region of the antibody genes, therefore, the original isotype of the sorted antibodies is not known. All the isolated antibodies were cloned with an IgG1 constant region, which may affect the binding properties of the cloned antibodies.

\section{Antibody production}

IgGs were expressed by transient transfection in HEK293-6E cells and purified from cell supernatants using protein A or G (GE Healthcare) as previously described (Escolano et al., 2019; Wang et al., 2020).

\section{ELISA}

ELISAs using BG505 SOSIP directly coated on a 96-well plate (Life Sciences, \#9018) were performed as previously described (Escolano et al., 2019). Briefly, high affinity 96-well flat bottom plates were coated with the SOSIP at $2 \mu \mathrm{g} / \mathrm{mL}$ and incubated overnight at $4^{\circ} \mathrm{C}$. The plates were washed three times with PBS-0.05\% Tween 20 and blocked with $2 \%$ of milk for $1 \mathrm{hr}$ at RT. After blocking, monoclonal antibodies were added to the plate at 3-fold serial dilutions starting at $10 \mu \mathrm{g} / \mathrm{mL}$ and incubated for $2 \mathrm{hr}$ at RT. Binding was developed with a horseradish peroxidase (HRP)-conjugated anti-human IgG secondary antibody (Jackson ImmunoResearch, 109-035-088) and using ABTS as the HRP substrate.

For competition ELISA, 96-well flat bottom plates were first coated with streptavidin $(2 \mu \mathrm{g} / \mathrm{mL})$ at $37^{\circ} \mathrm{C}$ for $1 \mathrm{hr}$, then washed and blocked with $2 \%$ milk and incubated with biotinylated BG505 SOSIP $\left(2 \mu \mathrm{g} / \mathrm{mL}\right.$ ) at $37^{\circ} \mathrm{C}$ for $1 \mathrm{hr}$. Competing bNAb Fabs (10-1074, 3BNC117, 8ANC195, VRC34, and PG9) were added at $10 \mu \mathrm{g} / \mathrm{mL}$ to the plates for $1 \mathrm{hr}$ at $37^{\circ} \mathrm{C}$. After wash, serially diluted mAbs were added and incubated at $37^{\circ} \mathrm{C}$ for $2 \mathrm{hr}$. The binding was detected by an HRP-conjugated anti-human IgG 
(Fc) $\mathrm{CH} 2$ Domain antibody (Bio-Rad MCA647P) used at a 1:5000 dilution at RT for $1 \mathrm{hr}$ and developed as described above.

\section{Polyreactivity assay}

ELISAs to determine antibody binding to LPS, KLH, single stranded DNA, dsDNA and insulin were previously described in Gitlin et al., 2016. ED38 (Wardemann et al., 2003; Meffre et al., 2004) and mG053 (Yurasov et al., 2005) antibodies were used as positive and negative controls.

\section{Antibody pharmacokinetic analysis}

Female B6. Cg-Fcgrt ${ }^{\text {tm1Dcr }}$ Tg(CAG-FCGRT)276Dcr/DcrJ mice (FcRn -/- hFcRn) (The Jackson Laboratory, \#004919) aged 7-8 weeks were intravenously injected (Retro-orbital vein) with $0.5 \mathrm{mg}$ of purified Ab1485-macaque-LS in PBS. Total serum concentrations of human IgG were determined by ELISA as previously described with minor modifications (Klein et al., 2012). In brief, high-binding ELISA plates (Corning) were coated with Goat Anti-Human IgG (Jackson ImmunoResearch \#109-005098) at a concentration of $2.5 \mu \mathrm{g} / \mathrm{mL}$ overnight at RT. Subsequently, wells were blocked with blocking buffer (2\% BSA (SIGMA), $1 \mathrm{mM}$ EDTA (Thermo Fisher), and 0.1\% Tween 20 (Thermo Fisher) in PBS). A standard curve was prepared using human lgG1 kappa purified from myeloma plasma (Sigma-Aldrich). Serial dilutions of the IgG standard (in duplicates) and serum samples in PBS were incubated for $60 \mathrm{~min}$ at 37C, followed by HRP-conjugated anti-human IgG (Jackson ImmunoResearch \#109-035-008) diluted 1: 5000 in blocking buffer for $60 \mathrm{~min}$ at RT. Following the addition of TMB (Thermo Fisher \#34021) for $8 \mathrm{~min}$ and stop solution, optical density at $450 \mathrm{~nm}$ was determined using a microplate reader (BMG Labtech). Plates were washed with $0.05 \%$ Tween 20 in PBS between each step. The elimination half-life was calculated using pharmacokinetics parameters estimated by performing a non-compartmental analysis (NCA) using WinNonlin 6.3 (Certara Software).

\section{In vitro neutralization assays}

The neutralization activity of monoclonal antibodies was assessed using TZM-bl cells as described previously (Sarzotti-Kelsoe et al., 2014). Two or three technical replicates per sample were assayed.

\section{Protein expression and purification for structural studies}

Ab1485 and 8ANC195 Fabs were recombinantly expressed by transiently transfecting Expi293F cells (Invitrogen) with vectors encoding antibody light chain and C-terminal hexahistidine-tagged heavy chain genes. Secreted Fabs were purified from cell supernatants harvested four days post-transfection using $\mathrm{Ni}^{2+}$-NTA affinity chromatography (GE Healthcare), followed by size exclusion chromatography (SEC) with a Superdex 16/60 column (GE Healthcare). Purified Fabs were concentrated and stored at $4{ }^{\circ} \mathrm{C}$ in storage buffer ( $20 \mathrm{mM}$ Tris $\mathrm{pH} 8.0,120 \mathrm{mM} \mathrm{NaCl}, 0.02 \%$ sodium azide).

A gene encoding soluble BG505 SOSIP.664 v4.1 gp140 trimer (Sanders et alo, 2013) was stably expressed in Chinese hamster ovary cells (kind gift of John Moore, Weill Cornell Medical College) as described (Dey et al., 2018). Secreted Env trimers were isolated using PGT145 immunoaffinity chromatography by covalently coupling PGT145 lgG monomer to an activated-NHS Sepharose column (GE Healthcare) as previously described (Dey et al., 2018). Properly folded trimers were eluted with $3 \mathrm{M} \mathrm{MgCl} 2$ and immediately dialyzed into storage buffer before being subjected to multiple size exclusion chromatography runs with a Superdex200 16/60 column followed by a Superose6 10/300 column (GE Healthcare). Peak fractions verified to be BG505 SOSIP. 664 trimers were stored as individual fractions at $4{ }^{\circ} \mathrm{C}$ in storage buffer.

\section{Cryo-EM sample preparation}

Complexes of Ab1485-BG505-8ANC195 were assembled by incubating purified Fabs with BG505 trimers at a 3:1 Fab:gp140 protomer ratio overnight at room temperature. Complexes were purified from excess Fab by size exclusion chromatography using a Superose-6 10/300 column (GE Healthcare). Peak fractions corresponding to the Ab1485-BG505-8ANC195 complex were concentrated to $1.5 \mathrm{mg} / \mathrm{mL}$ in $20 \mathrm{mM}$ Tris $\mathrm{pH}$ 8.0, $100 \mathrm{mM} \mathrm{NaCl}$ and deposited onto a 400 mesh, 1.2/1.3 Quantifoil grid (Electron Microscopy Sciences) that had been freshly glow-discharged for $45 \mathrm{~s}$ at $20 \mathrm{~mA}$ using a PELCO easiGLOW (Ted Pella). Samples were vitrified in 100\% liquid ethane using a Mark IV Virtobot 
(Thermo Fisher) after blotting for $3 \mathrm{~s}$ with Whatman No. one filter paper at $22{ }^{\circ} \mathrm{C}$ and $100 \%$ humidity.

\section{Cryo-EM data collection, processing, and model refinement}

Movies of the Ab1485-BG505-8ANC195 complex were collected on a Talos Arctica transmission electron microscope (Thermo Fisher) operating at $200 \mathrm{kV}$ using SerialEM automated data collection software (Mastronarde, 2005) and equipped with a Gatan K3 Summit direct electron detector. Movies were obtained in counting mode at a nominal magnification of 45,000x (super-resolution 0.435 $\AA$ /pixel) using a defocus range of -1.5 to $-3.0 \mu \mathrm{m}$, with a $3.6 \mathrm{~s}$ exposure time at a rate of $13.4 \mathrm{e}^{-} /$ $\mathrm{pix} / \mathrm{s}$, which resulted in a total dose of $60 \mathrm{e}^{-} / \AA^{2}$ over 40 frames.

Cryo-EM data processing was performed as previously described (Schoofs et al., 2019). Briefly, movie frame alignment was carried out with MotionCorr2 (Zheng et al., 2017) with dose weighting, followed by CTF estimation in GCTF (Zhang, 2016). After manual curation of micrographs, reference-free particle picking was conducted using Laplacian-of-Gaussian filtering in RELION-3.0. Extracted particles were binned $\times 4$ (3.47 $\AA$ /pixel), and subjected to reference-free 2D classification with a $220 \AA$ circular mask. Class averages that represented different views of the Fab bound Env-trimer and displayed secondary structural elements were selected ( 641,000 particles) and an ab initio model was generated using cryoSPARC v2.12 (Punjani et al., 2017).

The generated volume was used as an initial model for iterative rounds of 3D classification ( $C 1$ symmetry, $k=6$ ) in RELION 3.0. Particles corresponding to 3D class averages that displayed the highest resolution features were re-extracted unbinned $(0.869 \AA$ A/pixel) and homogenously 3Drefined with a soft mask in which Fab constant domains were masked out, resulting in an estimated resolution of $4.1 \AA$ according to gold-standard FSC (Bell et al., 2016). To further improve the resolution, particles were further $3 D$ classified $(k=6$, tau_fudge $=10)$, polished, and CTF refined. The final particle stack of $\sim 404,000$ particles refined to a final estimated resolution of $3.54 \AA$ (C1 symmetry) according to gold-standard FSC.

To generate initial coordinates, reference models (gp120-gp41, PDB: 6UDJ; 8ANC195 Fab, 4PNM) were docked into the final reconstructed density using UCSF Chimera v1.13 (Goddard et al., 2007). For the Ab1485, initial coordinates were generated by docking a 10-1074 Fab model (PDB 4FQQ), which had been altered by removing Fab CDR loops, into the cryo-EM density at the V3/ N332-glycan epitope. Prior to initial refinement, 10-1074 $\mathrm{V}_{\mathrm{H}}-\mathrm{V}_{\mathrm{L}}$ sequences were mutated to match Ab1485 and manually refined into density in Coot (Emsley et al., 2010). The full model was then refined into the cryo-EM maps using one round of rigid body refinement, morphing, and simulated annealing followed by several rounds of B-factor refinement in Phenix (Adams et al., 2010). Models were manually built following iterative rounds of real-space and B-factor refinement in Coot and Phenix with secondary structure restraints. Modeling of glycans was achieved by interpreting cryo-EM density at possible $\mathrm{N}$-linked glycosylation sites in Coot. Validation of model coordinates was performed using MolProbity (Chen et al., 2010) and figures were rendered using UCSF Chimera or PyMOL (Version 1.5.0.4 Schrodinger, LLC). Buried surface areas and potential hydrogen bonds were determined as previously described (Schoofs et al., 2019).

\section{Surface Plasmon Resonance}

SPR experiments were performed using a Biacore T200 instrument (GE Healthcare). RC1 SOSIP (Escolano et al., 2019), RC1 glycan-KO ${ }^{324}$ GAIA ${ }^{327}$ SOSIP (Escolano et al., 2019) and BG505 SOSIP (Escolano et al., 2019) (were immobilized on a CM5 chip by primary amine chemistry (Biacore manual)). Flow cell one was kept empty and reserved as a negative control. A concentration series of $1485 \mathrm{Fab}$ (3-fold dilutions from a top concentration of $100 \mathrm{nM}$ ) was injected at $30 \mu \mathrm{l} / \mathrm{min}$ for $60 \mathrm{~s}$ followed by a dissociation phase of $300 \mathrm{~s}$. Binding reactions were allowed to reach equilibrium and $K_{\mathrm{D}}$ values were calculated from the ratio of association and dissociation constants $\left(K_{\mathrm{D}}=k_{\mathrm{d}} / k_{\mathrm{a}}\right)$, which were derived using a 1:1 binding model that was globally fit to all curves in a data set. Flow cells were regenerated with $10 \mathrm{mM}$ glycine $\mathrm{pH} 3.0$ at a flow rate of $90 \mu \mathrm{l} / \mathrm{min}$ for $30 \mathrm{~s}$.

\section{Virus challenge}

A single dose (10 mg/kg body weight) of Ab1485 was infused intravenously into four Indian rhesus macaques (DH18, DH27, DH29, and DHAP). $24 \mathrm{hr}$ following Ab infusion, these animals were 
inoculated intrarectally with a high dose $\left(1000 \mathrm{TCID}_{50}\right)$ challenge of $\mathrm{SHIV}_{\mathrm{AD} 8}$. Two control monkeys (FZH and JG7), receiving no Ab, were reported in a previous study (Yamamoto, 2015). A pediatric speculum was used to gently open the rectum and a $1 \mathrm{~mL}$ suspension of virus in a tuberculin syringe was slowly infused into rectal cavity. Blood was drawn regularly to monitor viral infection and serum neutralizing activity. Rhesus macaques were housed and cared for in accordance with Guide for Care and Use of Laboratory Animals Report number NIH 82-53 (Department of Health and Human Services, Bethesda, Maryland, 1985) in a biosafety level 2 National Institute of Allergy and Infectious Diseases (NIAID) facility. All animal procedures and experiments were performed according to LMM32E protocol approved by the Institutional Animal Care and Use Committee of NIAID, NIH.

\section{Authentication of cell lines}

Cell lines were obtained from and authenticated by vendors or scientific collaborators. The cell lines were not contaminated by mycoplasma as determined by using the Lonza Mycoplasma Detection Kit.

\section{Analysis}

MacVector v.17.0.2 was used for sequence analysis. Flow cytometry data were processed using FlowJo v.10.6.1 and FCS EXPRESS. GraphPad Prism seven was used for data analysis. Immunoglobulin gene sequence $A B 1$ files were converted to FASTO format using SeqlO from Biopython (Cock et al., 2009). In the quality control step, non-determined and low-quality nucleotides were trimmed from both $5^{\prime}$ and $3^{\prime}$ ends of the sequence present in the FASTO files using cutadapt v.2.3 software. IgBlast was used to identify immunoglobulin $V(D) J$ genes and consequently the junction region, which was further used to define the Ig clones by Change-O toolkit v.0.4.5 (Gupta et al., 2015). Clones were defined by calculating and normalizing the hamming distance of the junction region and comparing it to a pre-defined threshold of 0.15 .

\section{Acknowledgements}

We thank members of the Bjorkman, Martin and Nussenzweig laboratories for discussions. Cryo-EM was performed in the Beckman Institute Resource Center for Transmission Electron Microscopy at Caltech with assistance from directors A Malyutin and S Chen. We thank J Vielmetter and the Beckman Institute Protein Expression Center at Caltech for protein production, John Moore (Weill Cornell Medical College) for the BG505 stable cell line and Rogier W Sanders (Amsterdam UMC) and Marit J van Gils (Amsterdam UMC) for providing BG505 SOSIP trimers. This work was supported by NIH Center for HIV/AIDS Vaccine Immunology and Immunogen Discovery (CHAVI-ID) 1 UM1 AI100663-01 (to MCN), the National Institute of Allergy and Infectious Diseases (NIAID) HIVRAD P01 AI100148 (to MCN and PJB), the Bill and Melinda Gates Foundation Collaboration for AIDS Vaccine Discovery (CAVD) grant INV-002143 (to MAM, MCN, PJB), the Intramural Research Program of the NIAID, NIH (to MAM) and the Bill and Melinda Gates Foundation (CAVD) grant \#OPP1146996 (to MSS). Additional support included the NIH K99/R00 grant (9694871) (to AE), the HHMI Hanna Gray Fellowship and the Postdoctoral Enrichment Program from the Burroughs Welcome Fund (to COB).

\section{Additional information}

Competing interests

Pamela J Bjorkman: Reviewing editor, eLife. The other authors declare that no competing interests exist.

Funding

Funder Grant reference number Author

NIH Center for HIV/AIDS Vac- 1UM1 Al100663-01_ Michel C Nussenzweig cine Immunology and Immunogen Discovery

National Institute of Allergy HIVRAD P01Al100148 Pamela J Bjorkman




\begin{tabular}{|c|c|c|}
\hline and Infectious Diseases & & Michel C Nussenzweig \\
\hline $\begin{array}{l}\text { Bill and Melinda Gates Foun- } \\
\text { dation }\end{array}$ & $\begin{array}{l}\text { Collaboration for AIDS } \\
\text { Vaccine Discovery INV- } \\
002143\end{array}$ & $\begin{array}{l}\text { Malcolm Martin } \\
\text { Pamela J Bjorkman } \\
\text { Michel C Nussenzweig }\end{array}$ \\
\hline $\begin{array}{l}\text { National Institute of Allergy } \\
\text { and Infectious Diseases }\end{array}$ & $\begin{array}{l}\text { Intramural Research } \\
\text { Program of the NIAID }\end{array}$ & Malcolm Martin \\
\hline $\begin{array}{l}\text { Bill and Melinda Gates Foun- } \\
\text { dation }\end{array}$ & OPP1146996 & Michael S Seaman \\
\hline National Institutes of Health & K99/R00 grant 9694871 & Amelia Escolano \\
\hline $\begin{array}{l}\text { Howard Hughes Medical Insti- } \\
\text { tute }\end{array}$ & Hanna Gray Fellowship & Christopher O Barnes \\
\hline Burroughs Wellcome Fund & $\begin{array}{l}\text { Postdoctoral Enrichment } \\
\text { Program }\end{array}$ & Christopher O Barnes \\
\hline
\end{tabular}

The funders had no role in study design, data collection and interpretation, or the decision to submit the work for publication.

Author contributions

Zijun Wang, Data curation, Formal analysis, Investigation, Methodology; Christopher O Barnes, Conceptualization, Data curation, Formal analysis, Funding acquisition, Investigation, Methodology, Writing - original draft; Rajeev Gautam, Conceptualization, Data curation, Formal analysis, Investigation, Methodology, Writing - original draft, Writing - review and editing; Julio C Cetrulo Lorenzi, Christian T Mayer, Melissa Cipolla, Kristie M Gordon, Harry B Gristick, Yoshiaki Nishimura, Henna Raina, Methodology; Thiago Y Oliveira, Victor Ramos, Software; Anthony P West, Formal analysis; Michael S Seaman, Supervision, Funding acquisition, Methodology; Anna Gazumyan, Supervision, Methodology; Malcolm Martin, Michel C Nussenzweig, Conceptualization, Supervision, Funding acquisition, Writing - original draft, Project administration, Writing - review and editing; Pamela J Bjorkman, Supervision, Funding acquisition, Writing - original draft, Project administration, Writing - review and editing; Amelia Escolano, Conceptualization, Data curation, Formal analysis, Supervision, Funding acquisition, Investigation, Methodology, Writing - original draft, Project administration, Writing - review and editing

\section{Author ORCIDs}

Victor Ramos (iD http://orcid.org/0000-0001-7353-3420

Pamela J Bjorkman (iD) http://orcid.org/0000-0002-2277-3990

Amelia Escolano (D) https://orcid.org/0000-0002-1945-2440

Ethics

Animal experimentation: Rhesus macaques were housed and cared for in accordance with Guide for Care and Use of Laboratory Animals Report number NIH 82-53 (Department of Health and Human Services, Bethesda, Maryland, 1985) in a biosafety level 2 National Institute of Allergy and Infectious Diseases (NIAID) facility. All animal procedures and experiments were performed according to LMM32E protocol approved by the Institutional Animal Care and Use Committee of NIAID, NIH.

Decision letter and Author response

Decision letter https://doi.org/10.7554/eLife.61991.sa1

Author response https://doi.org/10.7554/eLife.61991.sa2

\section{Additional files}

Supplementary files

- Transparent reporting form 
Data availability

Sequencing data has been provided for all the antibodies reported on the manuscript. Coordinates and corresponding 3D EM reconstructions for the Ab1485-BG505-8ANC195 trimer complex have been deposited in the PDB and EMDB, under accession numbers PDB: 7KDE and EMD: 22820.

The following datasets were generated:

\begin{tabular}{|c|c|c|c|c|}
\hline Author(s) & Year & Dataset title & Dataset URL & $\begin{array}{l}\text { Database and } \\
\text { Identifier }\end{array}$ \\
\hline $\begin{array}{l}\text { Barnes CO, Bjork- } \\
\text { man PJ }\end{array}$ & 2020 & $\begin{array}{l}\text { BG505 SOSIP.664 in complex with } \\
\text { the V3-targeting rhesus macaque } \\
\text { antibody } 1485 \text { and human gp120- } \\
\text { gp41 interface antibody 8ANC195 }\end{array}$ & $\begin{array}{l}\text { https://www.rcsb.org/ } \\
\text { structure/7KDE }\end{array}$ & $\begin{array}{l}\text { RCSB Protein Data } \\
\text { Bank, 7KDE }\end{array}$ \\
\hline $\begin{array}{l}\text { Barnes CO, Bjork- } \\
\text { man PJ }\end{array}$ & 2020 & $\begin{array}{l}\text { BG505 SOSIP.664 in complex with } \\
\text { the V3-targeting rhesus macaque } \\
\text { antibody } 1485 \text { and human gp120- }\end{array}$ & $\begin{array}{l}\text { https://www.ebi.ac.uk/ } \\
\text { pdbe/entry/emdb/EMD- } \\
22820\end{array}$ & $\begin{array}{l}\text { Electron Microscopy } \\
\text { Data Bank, EMD- } \\
22820\end{array}$ \\
\hline
\end{tabular}

\section{References}

Adams PD, Afonine PV, Bunkóczi G, Chen VB, Davis IW, Echols N, Headd JJ, Hung LW, Kapral GJ, GrosseKunstleve RW, McCoy AJ, Moriarty NW, Oeffner R, Read RJ, Richardson DC, Richardson JS, Terwilliger TC, Zwart PH. 2010. PHENIX: a comprehensive Python-based system for macromolecular structure solution. Acta Crystallographica Section D Biological Crystallography 66:213-221. DOI: https://doi.org/10.1107/ S0907444909052925, PMID: 20124702

Baba TW, Liska V, Hofmann-Lehmann R, Vlasak J, Xu W, Ayehunie S, Cavacini LA, Posner MR, Katinger H, Stiegler G, Bernacky BJ, Rizvi TA, Schmidt R, Hill LR, Keeling ME, Lu Y, Wright JE, Chou TC, Ruprecht RM. 2000. Human neutralizing monoclonal antibodies of the lgG1 subtype protect against mucosal simian-human immunodeficiency virus infection. Nature Medicine 6:200-206. DOl: https://doi.org/10.1038/72309, PMID: 10655110

Barnes CO, Gristick HB, Freund NT, Escolano A, Lyubimov AY, Hartweger H, West AP, Cohen AE, Nussenzweig MC, Bjorkman PJ. 2018. Structural characterization of a highly-potent V3-glycan broadly neutralizing antibody bound to natively-glycosylated HIV-1 envelope. Nature Communications 9:1251. DOI: https://doi.org/10.1038/ s41467-018-03632-y, PMID: 29593217

Barouch DH, Whitney JB, Moldt B, Klein F, Oliveira TY, Liu J, Stephenson KE, Chang HW, Shekhar K, Gupta S, Nkolola JP, Seaman MS, Smith KM, Borducchi EN, Cabral C, Smith JY, Blackmore S, Sanisetty S, Perry JR, Beck $M$, et al. 2013. Therapeutic efficacy of potent neutralizing HIV-1-specific monoclonal antibodies in SHIVinfected rhesus monkeys. Nature 503:224-228. DOI: https://doi.org/10.1038/nature12744, PMID: 24172905

Bell JM, Chen M, Baldwin PR, Ludtke SJ. 2016. High resolution single particle refinement in EMAN2.1. Methods 100:25-34. DOI: https://doi.org/10.1016/j.ymeth.2016.02.018, PMID: 26931650

Bhiman JN, Anthony C, Doria-Rose NA, Karimanzira O, Schramm CA, Khoza T, Kitchin D, Botha G, Gorman J, Garrett NJ, Abdool Karim SS, Shapiro L, Williamson C, Kwong PD, Mascola JR, Morris L, Moore PL. 2015. Viral variants that initiate and drive maturation of V1V2-directed HIV-1 broadly neutralizing antibodies. Nature Medicine 21:1332-1336. DOI: https://doi.org/10.1038/nm.3963, PMID: 26457756

Binley JM, Lybarger EA, Crooks ET, Seaman MS, Gray E, Davis KL, Decker JM, Wycuff D, Harris L, Hawkins N, Wood B, Nathe C, Richman D, Tomaras GD, Bibollet-Ruche F, Robinson JE, Morris L, Shaw GM, Montefiori DC, Mascola JR. 2008. Profiling the specificity of neutralizing antibodies in a large panel of plasmas from patients chronically infected with human immunodeficiency virus type 1 subtypes $B$ and C. Journal of Virology $\mathbf{8 2}$ : 11651-11668. DOI: https://doi.org/10.1128/JVI.01762-08, PMID: 18815292

Bonsignori M, Hwang KK, Chen X, Tsao CY, Morris L, Gray E, Marshall DJ, Crump JA, Kapiga SH, Sam NE, Sinangil F, Pancera M, Yongping Y, Zhang B, Zhu J, Kwong PD, O'Dell S, Mascola JR, Wu L, Nabel GJ, et al. 2011. Analysis of a clonal lineage of HIV-1 envelope V2/V3 conformational epitope-specific broadly neutralizing antibodies and their inferred unmutated common ancestors. Journal of Virology 85:9998-10009. DOI: https:// doi.org/10.1128/JVI.05045-11, PMID: 21795340

Bonsignori M, Zhou T, Sheng Z, Chen L, Gao F, Joyce MG, Ozorowski G, Chuang GY, Schramm CA, Wiehe K, Alam SM, Bradley T, Gladden MA, Hwang KK, lyengar S, Kumar A, Lu X, Luo K, Mangiapani MC, Parks RJ, et al. 2016. Maturation pathway from germline to broad HIV-1 neutralizer of a CD4-Mimic antibody. Cell 165: 449-463. DOI: https://doi.org/10.1016/j.cell.2016.02.022, PMID: 26949186

Bonsignori M, Kreider EF, Fera D, Meyerhoff RR, Bradley T, Wiehe K, Alam SM, Aussedat B, Walkowicz WE, Hwang KK, Saunders KO, Zhang R, Gladden MA, Monroe A, Kumar A, Xia SM, Cooper M, Louder MK, McKee K, Bailer RT, et al. 2017. Staged induction of HIV-1 glycan-dependent broadly neutralizing antibodies. Science Translational Medicine 9:eaai7514. DOI: https://doi.org/10.1126/scitrans/med.aai7514, PMID: 28298420

Burton DR, Hangartner L. 2016. Broadly neutralizing antibodies to HIV and their role in vaccine design. Annual Review of Immunology 34:635-659. DOI: https://doi.org/10.1146/annurev-immunol-041015-055515, PMID: 27168247 
Chen VB, Arendall WB, Headd JJ, Keedy DA, Immormino RM, Kapral GJ, Murray LW, Richardson JS, Richardson DC. 2010. MolProbity: all-atom structure validation for macromolecular crystallography. Acta Crystallographica Section D Biological Crystallography 66:12-21. DOI: https://doi.org/10.1107/S0907444909042073, PMID: 20057044

Chung NPY, Matthews K, Kim HJ, Ketas TJ, Golabek M, de los Reyes K, Korzun J, Yasmeen A, Sanders RW, Klasse P, Wilson IA, Ward AB, Marozsan AJ, Moore JP, Cupo A. 2014. Stable 293 T and CHO cell lines expressing cleaved, stable HIV-1 envelope glycoprotein trimers for structural and vaccine studies. Retrovirology 11:33. DOI: https://doi.org/10.1186/1742-4690-11-33

Cock PJ, Antao T, Chang JT, Chapman BA, Cox CJ, Dalke A, Friedberg I, Hamelryck T, Kauff F, Wilczynski B, de Hoon MJ. 2009. Biopython: freely available Python tools for computational molecular biology and bioinformatics. Bioinformatics 25:1422-1423. DOI: https://doi.org/10.1093/bioinformatics/btp163, PMID: 1 9304878

Dey AK, Cupo A, Ozorowski G, Sharma VK, Behrens AJ, Go EP, Ketas TJ, Yasmeen A, Klasse PJ, Sayeed E, Desaire H, Crispin M, Wilson IA, Sanders RW, Hassell T, Ward AB, Moore JP. 2018. cGMP production and analysis of BG505 SOSIP.664, an extensively glycosylated, trimeric HIV-1 envelope glycoprotein vaccine candidate. Biotechnology and Bioengineering 115:885-899. DOI: https://doi.org/10.1002/bit.26498, PMID: 2 9150937

Dimitrov DS. 2010. Therapeutic antibodies, vaccines and antibodyomes. mAbs 2:347-356. DOI: https://doi.org/ 10.4161/mabs.2.3.11779, PMID: 20400863

Doria-Rose NA, Klein RM, Manion MM, O'Dell S, Phogat A, Chakrabarti B, Hallahan CW, Migueles SA, Wrammert J, Ahmed R, Nason M, Wyatt RT, Mascola JR, Connors M. 2009. Frequency and phenotype of human immunodeficiency virus envelope-specific $B$ cells from patients with broadly cross-neutralizing antibodies. Journal of Virology 83:188-199. DOI: https://doi.org/10.1128/JVI.01583-08, PMID: 18922865

Doria-Rose NA, Schramm CA, Gorman J, Moore PL, Bhiman JN, DeKosky BJ, Ernandes MJ, Georgiev IS, Kim HJ, Pancera M, Staupe RP, Altae-Tran HR, Bailer RT, Crooks ET, Cupo A, Druz A, Garrett NJ, Hoi KH, Kong R, Louder MK, et al. 2014. Developmental pathway for potent V1V2-directed HIV-neutralizing antibodies. Nature 509:55-62. DOI: https://doi.org/10.1038/nature13036, PMID: 24590074

Dosenovic P, von Boehmer L, Escolano A, Jardine J, Freund NT, Gitlin AD, McGuire AT, Kulp DW, Oliveira T, Scharf L, Pietzsch J, Gray MD, Cupo A, van Gils MJ, Yao KH, Liu C, Gazumyan A, Seaman MS, Björkman PJ, Sanders RW, et al. 2015. Immunization for HIV-1 broadly neutralizing antibodies in human ig knockin mice. Cell 161:1505-1515. DOI: https://doi.org/10.1016/j.cell.2015.06.003, PMID: 26091035

Eichberg JW, Murthy KK, Ward RH, Prince AM. 1992. Prevention of HIV infection by passive immunization with HIVIG or CD4-lgG. AIDS Research and Human Retroviruses 8:1515. DOI: https://doi.org/10.1089/aid.1992.8. 1515, PMID: 1466993

Emini EA, Schleif WA, Nunberg JH, Conley AJ, Eda Y, Tokiyoshi S, Putney SD, Matsushita S, Cobb KE, Jett CM. 1992. Prevention of HIV-1 infection in chimpanzees by gp120 V3 domain-specific monoclonal antibody. Nature 355:728-730. DOI: https://doi.org/10.1038/355728a0, PMID: 1741059

Emsley P, Lohkamp B, Scott WG, Cowtan K. 2010. Features and development of coot. Acta Crystallographica. Section D, Biological Crystallography 66:486-501. DOI: https://doi.org/10.1107/S0907444910007493, PMID: 20383002

Escolano A, Steichen JM, Dosenovic P, Kulp DW, Golijanin J, Sok D, Freund NT, Gitlin AD, Oliveira T, Araki T, Lowe S, Chen ST, Heinemann J, Yao KH, Georgeson E, Saye-Francisco KL, Gazumyan A, Adachi Y, Kubitz M, Burton DR, et al. 2016. Sequential immunization elicits broadly neutralizing Anti-HIV-1 antibodies in ig knockin mice. Cell 166:1445-1458. DOI: https://doi.org/10.1016/j.cell.2016.07.030, PMID: 27610569

Escolano A, Gristick HB, Abernathy ME, Merkenschlager J, Gautam R, Oliveira TY, Pai J, West AP, Barnes CO Cohen AA, Wang H, Golijanin J, Yost D, Keeffe JR, Wang Z, Zhao P, Yao KH, Bauer J, Nogueira L, Gao H, et al. 2019. Immunization expands B cells specific to HIV-1 V3 glycan in mice and macaques. Nature 570:468-473. DOI: https://doi.org/10.1038/s41586-019-1250-z, PMID: 31142836

Freund NT, Wang H, Scharf L, Nogueira L, Horwitz JA, Bar-On Y, Golijanin J, Sievers SA, Sok D, Cai H, Cesar Lorenzi JC, Halper-Stromberg A, Toth I, Piechocka-Trocha A, Gristick HB, van Gils MJ, Sanders RW, Wang LX, Seaman MS, Burton DR, et al. 2017. Coexistence of potent HIV-1 broadly neutralizing antibodies and antibodysensitive viruses in a viremic controller. Science Translational Medicine 9:eaal2144. DOI: https://doi.org/10. 1126/scitranslmed.aal2144, PMID: 28100831

Garces F, Sok D, Kong L, McBride R, Kim HJ, Saye-Francisco KF, Julien JP, Hua Y, Cupo A, Moore JP, Paulson JC, Ward AB, Burton DR, Wilson IA. 2014. Structural evolution of glycan recognition by a family of potent HIV antibodies. Cell 159:69-79. DOI: https://doi.org/10.1016/j.cell.2014.09.009, PMID: 25259921

Gautam R, Nishimura Y, Lee WR, Donau O, Buckler-White A, Shingai M, Sadjadpour R, Schmidt SD, LaBranche CC, Keele BF, Montefiori D, Mascola JR, Martin MA. 2012. Pathogenicity and mucosal transmissibility of the R5-tropic simian/human immunodeficiency virus SHIV(AD8) in rhesus macaques: implications for use in vaccine studies. Journal of Virology 86:8516-8526. DOI: https://doi.org/10.1128/JVI.00644-12, PMID: 22647691

Gitlin AD, von Boehmer L, Gazumyan A, Shulman Z, Oliveira TY, Nussenzweig MC. 2016. Independent roles of switching and hypermutation in the development and persistence of B lymphocyte memory. Immunity 44:769781. DOI: https://doi.org/10.1016/j.immuni.2016.01.011, PMID: 26944202

Goddard TD, Huang CC, Ferrin TE. 2007. Visualizing density maps with UCSF chimera. Journal of Structural Biology 157:281-287. DOI: https://doi.org/10.1016/j.jsb.2006.06.010, PMID: 16963278

Gray ES, Madiga MC, Hermanus T, Moore PL, Wibmer CK, Tumba NL, Werner L, Mlisana K, Sibeko S, Williamson C, Abdool Karim SS, Morris L, CAPRISA002 Study Team. 2011. The neutralization breadth of HIV-1 develops 
incrementally over four years and is associated with CD4+ T cell decline and high viral load during acute infection. Journal of Virology 85:4828-4840. DOI: https://doi.org/10.1128/JVI.00198-11, PMID: 21389135

Gristick HB, von Boehmer L, West AP, Schamber M, Gazumyan A, Golijanin J, Seaman MS, Fätkenheuer G, Klein F, Nussenzweig MC, Bjorkman PJ. 2016. Natively glycosylated HIV-1 env structure reveals new mode for antibody recognition of the CD4-binding site. Nature Structural \& Molecular Biology 23:906-915. DOI: https:// doi.org/10.1038/nsmb.3291, PMID: 27617431

Gruell H, Bournazos S, Ravetch JV, Ploss A, Nussenzweig MC, Pietzsch J. 2013. Antibody and antiretroviral preexposure prophylaxis prevent cervicovaginal HIV-1 infection in a transgenic mouse model. Journal of Virology 87:8535-8544. DOI: https://doi.org/10.1128/JVI.00868-13, PMID: 23720722

Gupta NT, Vander Heiden JA, Uduman M, Gadala-Maria D, Yaari G, Kleinstein SH. 2015. Change-O: a toolkit for analyzing large-scale B cell immunoglobulin repertoire sequencing data: Table 1. Bioinformatics 31:3356-3358. DOI: https://doi.org/10.1093/bioinformatics/btv359

Hessell AJ, Poignard P, Hunter M, Hangartner L, Tehrani DM, Bleeker WK, Parren PW, Marx PA, Burton DR. 2009a. Effective, low-titer antibody protection against low-dose repeated mucosal SHIV challenge in macaques. Nature Medicine 15:951-954. DOI: https://doi.org/10.1038/nm.1974, PMID: 19525965

Hessell AJ, Rakasz EG, Poignard P, Hangartner L, Landucci G, Forthal DN, Koff WC, Watkins DI, Burton DR. $2009 \mathrm{~b}$. Broadly neutralizing human anti-HIV antibody $2 \mathrm{~g} 12$ is effective in protection against mucosal SHIV challenge even at low serum neutralizing titers. PLOS Pathogens 5:e1000433. DOI: https://doi.org/10.1371/ journal.ppat.1000433, PMID: 19436712

Hessell AJ, Rakasz EG, Tehrani DM, Huber M, Weisgrau KL, Landucci G, Forthal DN, Koff WC, Poignard P, Watkins DI, Burton DR. 2010. Broadly neutralizing monoclonal antibodies $2 f 5$ and $4 E 10$ directed against the human immunodeficiency virus type $1 \mathrm{gp} 41$ membrane-proximal external region protect against mucosal challenge by simian-human immunodeficiency virus SHIVBa-L. Journal of Virology 84:1302-1313. DOI: https:// doi.org/10.1128/JVI.01272-09, PMID: 19906907

Hoot S, McGuire AT, Cohen KW, Strong RK, Hangartner L, Klein F, Diskin R, Scheid JF, Sather DN, Burton DR, Stamatatos L. 2013. Recombinant HIV envelope proteins fail to engage germline versions of anti-CD4bs bNAbs. PLOS Pathogens 9:e1003106. DOI: https://doi.org/10.1371/journal.ppat.1003106, PMID: 23300456

Horwitz JA, Halper-Stromberg A, Mouquet H, Gitlin AD, Tretiakova A, Eisenreich TR, Malbec M, Gravemann S, Billerbeck E, Dorner M, Büning H, Schwartz O, Knops E, Kaiser R, Seaman MS, Wilson JM, Rice CM, Ploss A, Bjorkman PJ, Klein F, et al. 2013. HIV-1 suppression and durable control by combining single broadly neutralizing antibodies and antiretroviral drugs in humanized mice. PNAS 110:16538-16543. DOI: https://doi. org/10.1073/pnas.1315295110, PMID: 24043801

Hraber P, Seaman MS, Bailer RT, Mascola JR, Montefiori DC, Korber BT. 2014. Prevalence of broadly neutralizing antibody responses during chronic HIV-1 infection. Aids 28:163-169. DOI: https://doi.org/10.1097/QAD. 0000000000000106, PMID: 24361678

Kepler TB, Liao HX, Alam SM, Bhaskarabhatla R, Zhang R, Yandava C, Stewart S, Anasti K, Kelsoe G, Parks R, Lloyd KE, Stolarchuk C, Pritchett J, Solomon E, Friberg E, Morris L, Karim SS, Cohen MS, Walter E, Moody MA, et al. 2014. Immunoglobulin gene insertions and deletions in the affinity maturation of HIV-1 broadly reactive neutralizing antibodies. Cell Host \& Microbe 16:304-313. DOI: https://doi.org/10.1016/j.chom.2014.08.006, PMID: 25211073

Klein F, Halper-Stromberg A, Horwitz JA, Gruell H, Scheid JF, Bournazos S, Mouquet H, Spatz LA, Diskin R, Abadir A, Zang T, Dorner M, Billerbeck E, Labitt RN, Gaebler C, Marcovecchio P, Incesu RB, Eisenreich TR, Bieniasz PD, Seaman MS, et al. 2012. HIV therapy by a combination of broadly neutralizing antibodies in humanized mice. Nature 492:118-122. DOI: https://doi.org/10.1038/nature11604, PMID: 23103874

Klein F, Diskin R, Scheid JF, Gaebler C, Mouquet H, Georgiev IS, Pancera M, Zhou T, Incesu RB, Fu BZ, Gnanapragasam PN, Oliveira TY, Seaman MS, Kwong PD, Bjorkman PJ, Nussenzweig MC. 2013. Somatic mutations of the immunoglobulin framework are generally required for broad and potent HIV-1 neutralization. Cell 153:126-138. DOI: https://doi.org/10.1016/j.cell.2013.03.018, PMID: 23540694

Kong L, Lee JH, Doores KJ, Murin CD, Julien JP, McBride R, Liu Y, Marozsan A, Cupo A, Klasse PJ, Hoffenberg S, Caulfield M, King CR, Hua Y, Le KM, Khayat R, Deller MC, Clayton T, Tien H, Feizi T, et al. 2013. Supersite of immune vulnerability on the glycosylated face of HIV-1 envelope glycoprotein gp120. Nature Structural \& Molecular Biology 20:796-803. DOI: https://doi.org/10.1038/nsmb.2594, PMID: 23708606

Kong L, Torrents de la Peña A, Deller MC, Garces F, Sliepen K, Hua Y, Stanfield RL, Sanders RW, Wilson IA. 2015. Complete epitopes for vaccine design derived from a crystal structure of the broadly neutralizing antibodies PGT128 and 8anc195 in complex with an HIV-1 env trimer. Acta Crystallographica Section D Biological Crystallography 71:2099-2108. DOI: https://doi.org/10.1107/S1399004715013917, PMID: 26457433

Kong R, Xu K, Zhou T, Acharya P, Lemmin T, Liu K, Ozorowski G, Soto C, Taft JD, Bailer RT, Cale EM, Chen L, Choi CW, Chuang GY, Doria-Rose NA, Druz A, Georgiev IS, Gorman J, Huang J, Joyce MG, et al. 2016. Fusion peptide of HIV-1 as a site of vulnerability to neutralizing antibody. Science 352:828-833. DOI: https://doi.org/ 10.1126/science.aae0474, PMID: 27174988

Landais E, Moore PL. 2018. Development of broadly neutralizing antibodies in HIV-1 infected elite neutralizers. Retrovirology 15:61. DOI: https://doi.org/10.1186/s12977-018-0443-0, PMID: 30185183

Li Y, Svehla K, Louder MK, Wycuff D, Phogat S, Tang M, Migueles SA, Wu X, Phogat A, Shaw GM, Connors M, Hoxie J, Mascola JR, Wyatt R. 2009. Analysis of neutralization specificities in polyclonal sera derived from human immunodeficiency virus type 1-infected individuals. Journal of Virology 83:1045-1059. DOI: https://doi. org/10.1128/JVI.01992-08, PMID: 19004942 
Liao HX, Lynch R, Zhou T, Gao F, Alam SM, Boyd SD, Fire AZ, Roskin KM, Schramm CA, Zhang Z, Zhu J, Shapiro L, Mullikin JC, Gnanakaran S, Hraber P, Wiehe K, Kelsoe G, Yang G, Xia SM, Montefiori DC, et al. 2013. Coevolution of a broadly neutralizing HIV-1 antibody and founder virus. Nature 496:469-476. DOI: https://doi. org/10.1038/nature12053, PMID: 23552890

Longo NS, Sutton MS, Shiakolas AR, Guenaga J, Jarosinski MC, Georgiev IS, McKee K, Bailer RT, Louder MK, O'Dell S, Connors M, Wyatt RT, Mascola JR, Doria-Rose NA. 2016. Multiple antibody lineages in one donor target the Glycan-V3 supersite of the HIV-1 envelope glycoprotein and display a preference for quaternary binding. Journal of Virology 90:10574-10586. DOI: https://doi.org/10.1128/JVI.01012-16, PMID: 27654288

Mascola JR, Lewis MG, Stiegler G, Harris D, VanCott TC, Hayes D, Louder MK, Brown CR, Sapan CV, Frankel SS, Lu Y, Robb ML, Katinger H, Birx DL. 1999. Protection of macaques against pathogenic simian/human immunodeficiency virus 89.6PD by passive transfer of neutralizing antibodies. Journal of Virology 73:4009_ 4018. DOI: https://doi.org/10.1128/JVI.73.5.4009-4018.1999, PMID: 10196297

Mascola JR, Stiegler G, VanCott TC, Katinger H, Carpenter CB, Hanson CE, Beary H, Hayes D, Frankel SS, Birx DL, Lewis MG. 2000. Protection of macaques against vaginal transmission of a pathogenic HIV-1/SIV chimeric virus by passive infusion of neutralizing antibodies. Nature Medicine 6:207-210. DOl: https://doi.org/10.1038/ 72318, PMID: 10655111

Mastronarde DN. 2005. Automated electron microscope tomography using robust prediction of specimen movements. Journal of Structural Biology 152:36-51. DOI: https://doi.org/10.1016/j.jsb.2005.07.007, PMID: 16182563

Meffre E, Schaefer A, Wardemann H, Wilson P, Davis E, Nussenzweig MC. 2004. Surrogate light chain expressing human peripheral B cells produce self-reactive antibodies. Journal of Experimental Medicine 199 145-150. DOI: https://doi.org/10.1084/jem.20031550, PMID: 14699083

Moldt B, Rakasz EG, Schultz N, Chan-Hui PY, Swiderek K, Weisgrau KL, Piaskowski SM, Bergman Z, Watkins DI, Poignard P, Burton DR. 2012. Highly potent HIV-specific antibody neutralization in vitro translates into effective protection against mucosal SHIV challenge in vivo. PNAS 109:18921-18925. DOI: https://doi.org/10.1073/ pnas.1214785109, PMID: 23100539

Montefiori DC. 2005. Evaluating neutralizing antibodies against HIV, SIV, and SHIV in luciferase reporter gene assays. Current Protocols in Immunology 12:11. DOI: https://doi.org/10.1002/0471142735.im1211s64, PMID: 1 8432938

Moore PL, Gray ES, Wibmer CK, Bhiman JN, Nonyane M, Sheward DJ, Hermanus T, Bajimaya S, Tumba NL, Abrahams MR, Lambson BE, Ranchobe N, Ping L, Ngandu N, Abdool Karim Q, Abdool Karim SS, Swanstrom RI, Seaman MS, Williamson C, Morris L. 2012. Evolution of an HIV glycan-dependent broadly neutralizing antibody epitope through immune escape. Nature Medicine 18:1688-1692. DOI: https://doi.org/10.1038/nm. 2985, PMID: 23086475

Mouquet H, Scharf L, Euler Z, Liu Y, Eden C, Scheid JF, Halper-Stromberg A, Gnanapragasam PN, Spencer DI, Seaman MS, Schuitemaker H, Feizi T, Nussenzweig MC, Bjorkman PJ. 2012. Complex-type N-glycan recognition by potent broadly neutralizing HIV antibodies. PNAS 109:E3268-E3277. DOI: https://doi.org/10 1073/pnas.1217207109, PMID: 23115339

Muster T, Steindl F, Purtscher M, Trkola A, Klima A, Himmler G, Rüker F, Katinger H. 1993. A conserved neutralizing epitope on gp41 of human immunodeficiency virus type 1. Journal of Virology 67:6642-6647. DOI: https://doi.org/10.1128/JVI.67.11.6642-6647.1993, PMID: 7692082

Nishimura Y, Shingai M, Willey R, Sadjadpour R, Lee WR, Brown CR, Brenchley JM, Buckler-White A, Petros R, Eckhaus M, Hoffman V, Igarashi T, Martin MA. 2010. Generation of the pathogenic R5-tropic simian/human immunodeficiency virus SHIVAD8 by serial passaging in rhesus macaques. Journal of Virology 84:4769-4781. DOI: https://doi.org/10.1128/JVI.02279-09, PMID: 20147396

Nishimura Y, Gautam R, Chun TW, Sadjadpour R, Foulds KE, Shingai M, Klein F, Gazumyan A, Golijanin J, Donaldson M, Donau OK, Plishka RJ, Buckler-White A, Seaman MS, Lifson JD, Koup RA, Fauci AS, Nussenzweig MC, Martin MA. 2017. Early antibody therapy can induce long-lasting immunity to SHIV. Nature 543:559-563. DOI: https://doi.org/10.1038/nature21435, PMID: 28289286

Pancera M, Zhou T, Druz A, Georgiev IS, Soto C, Gorman J, Huang J, Acharya P, Chuang GY, Ofek G, StewartJones GB, Stuckey J, Bailer RT, Joyce MG, Louder MK, Tumba N, Yang Y, Zhang B, Cohen MS, Haynes BF, et al. 2014. Structure and immune recognition of trimeric pre-fusion HIV-1 env. Nature 514:455-461. DOI: https://doi.org/10.1038/nature13808, PMID: 25296255

Parren PW, Marx PA, Hessell AJ, Luckay A, Harouse J, Cheng-Mayer C, Moore JP, Burton DR. 2001. Antibody protects macaques against vaginal challenge with a pathogenic R5 simian/human immunodeficiency virus at serum levels giving complete neutralization in vitro. Journal of Virology 75:8340-8347. DOI: https://doi.org/10. 1128/JVI.75.17.8340-8347.2001, PMID: 11483779

Pietzsch J, Gruell H, Bournazos S, Donovan BM, Klein F, Diskin R, Seaman MS, Bjorkman PJ, Ravetch JV, Ploss A, Nussenzweig MC. 2012. A mouse model for HIV-1 entry. PNAS 109:15859-15864. DOI: https://doi.org/10. 1073/pnas.1213409109, PMID: 23019371

Punjani A, Rubinstein JL, Fleet DJ, Brubaker MA. 2017. cryoSPARC: algorithms for rapid unsupervised cryo-EM structure determination. Nature Methods 14:290-296. DOI: https://doi.org/10.1038/nmeth.4169, PMID: 2 8165473

Roark RS, Li H, Williams WB, Chug H, Mason RD, Gorman J, Wang S, Lee F-H, Rando J, Bonsignori M, Hwang KK, Saunders KO, Wiehe K, Anthony Moody M, Hraber PT, Wagh K, Giorgi EE, Russell RM, Bibollet-Ruche F, Liu W, et al. 2020. Recapitulation of HIV-1 Env-Antibody coevolution in macaques leading to neutralization breadth. bioRxiv. DOI: https://doi.org/10.1101/2020.08.05.237693 
Roopenian DC, Christianson GJ, Sproule TJ, Brown AC, Akilesh S, Jung N, Petkova S, Avanessian L, Choi EY, Shaffer DJ, Eden PA, Anderson CL. 2003. The MHC class I-like IgG receptor controls perinatal IgG transport, IgG homeostasis, and fate of IgG-Fc-coupled drugs. The Journal of Immunology 170:3528-3533. DOI: https:// doi.org/10.4049/jimmunol.170.7.3528, PMID: 12646614

Rusert P, Kouyos RD, Kadelka C, Ebner H, Schanz M, Huber M, Braun DL, Hozé N, Scherrer A, Magnus C, Weber J, Uhr T, Cippa V, Thorball CW, Kuster H, Cavassini M, Bernasconi E, Hoffmann M, Calmy A, Battegay M, et al. 2016. Determinants of HIV-1 broadly neutralizing antibody induction. Nature Medicine 22:1260-1267. DOI: https://doi.org/10.1038/nm.4187, PMID: 27668936

Sadjadpour R, Donau OK, Shingai M, Buckler-White A, Kao S, Strebel K, Nishimura Y, Martin MA. 2013. Emergence of gp120 V3 variants confers neutralization resistance in an R5 simian-human immunodeficiency virus-infected macaque elite neutralizer that targets the N332 glycan of the human immunodeficiency virus type 1 envelope glycoprotein. Journal of Virology 87:8798-8804. DOl: https://doi.org/10.1128/JVI.00878-13, PMID: 23720719

Sanders RW, Derking R, Cupo A, Julien JP, Yasmeen A, de Val N, Kim HJ, Blattner C, de la Peña AT, Korzun J, Golabek M, de Los Reyes K, Ketas TJ, van Gils MJ, King CR, Wilson IA, Ward AB, Klasse PJ, Moore JP. 2013. A next-generation cleaved, soluble HIV-1 env trimer, BG505 SOSIP.664 gp140, expresses multiple epitopes for broadly neutralizing but not non-neutralizing antibodies. PLOS Pathogens 9:e1003618. DOI: https://doi.org/10. 1371/journal.ppat.1003618, PMID: 24068931

Sarzotti-Kelsoe M, Bailer RT, Turk E, Lin CL, Bilska M, Greene KM, Gao H, Todd CA, Ozaki DA, Seaman MS, Mascola JR, Montefiori DC. 2014. Optimization and validation of the TZM-bl assay for standardized assessments of neutralizing antibodies against HIV-1. Journal of Immunological Methods 409:131-146. DOI: https://doi.org/10.1016/j.jim.2013.11.022, PMID: 24291345

Sather DN, Armann J, Ching LK, Mavrantoni A, Sellhorn G, Caldwell Z, Yu X, Wood B, Self S, Kalams S, Stamatatos L. 2009. Factors associated with the development of cross-reactive neutralizing antibodies during human immunodeficiency virus type 1 infection. Journal of Virology 83:757-769. DOI: https://doi.org/10.1128/ JVI.02036-08, PMID: 18987148

Saunders KO, Verkoczy LK, Jiang C, Zhang J, Parks R, Chen H, Housman M, Bouton-Verville H, Shen X, Trama AM, Scearce R, Sutherland L, Santra S, Newman A, Eaton A, Xu K, Georgiev IS, Joyce MG, Tomaras GD, Bonsignori $\mathrm{M}$, et al. 2017. Vaccine induction of heterologous tier $2 \mathrm{HIV}-1$ neutralizing antibodies in animal models. Cell Reports 21:3681-3690. DOI: https://doi.org/10.1016/j.celrep.2017.12.028, PMID: 29281818

Saunders KO, Wiehe K, Tian M, Acharya P, Bradley T, Alam SM, Go EP, Scearce R, Sutherland L, Henderson R, Hsu AL, Borgnia MJ, Chen H, Lu X, Wu NR, Watts B, Jiang C, Easterhoff D, Cheng HL, McGovern K, et al. 2019. Targeted selection of HIV-specific antibody mutations by engineering B cell maturation. Science $\mathbf{3 6 6}$ : eaay7199. DOI: https://doi.org/10.1126/science.aay7199, PMID: 31806786

Scharf L, Scheid JF, Lee JH, West AP, Chen C, Gao H, Gnanapragasam PN, Mares R, Seaman MS, Ward AB, Nussenzweig MC, Bjorkman PJ. 2014. Antibody 8anc195 reveals a site of broad vulnerability on the HIV-1 envelope spike. Cell Reports 7:785-795. DOI: https://doi.org/10.1016/j.celrep.2014.04.001, PMID: 24767986

Scharf L, Wang H, Gao H, Chen S, McDowall AW, Bjorkman PJ. 2015. Broadly neutralizing antibody 8anc195 recognizes closed and open states of HIV-1 env. Cell 162:1379-1390. DOI: https://doi.org/10.1016/j.cell.2015 08.035, PMID: 26359989

Scheid JF, Mouquet H, Feldhahn N, Seaman MS, Velinzon K, Pietzsch J, Ott RG, Anthony RM, Zebroski H, Hurley A, Phogat A, Chakrabarti B, Li Y, Connors M, Pereyra F, Walker BD, Wardemann H, Ho D, Wyatt RT, Mascola JR, et al. 2009. Broad diversity of neutralizing antibodies isolated from memory B cells in HIV-infected individuals. Nature 458:636-640. DOI: https://doi.org/10.1038/nature07930, PMID: 19287373

Scheid JF, Mouquet H, Ueberheide B, Diskin R, Klein F, Oliveira TY, Pietzsch J, Fenyo D, Abadir A, Velinzon K, Hurley A, Myung S, Boulad F, Poignard P, Burton DR, Pereyra F, Ho DD, Walker BD, Seaman MS, Bjorkman PJ, et al. 2011. Sequence and structural convergence of broad and potent HIV antibodies that mimic CD4 binding. Science 333:1633-1637. DOI: https://doi.org/10.1126/science.1207227, PMID: 21764753

Schoofs T, Barnes CO, Suh-Toma N, Golijanin J, Schommers P, Gruell H, West AP, Bach F, Lee YE, Nogueira L, Georgiev IS, Bailer RT, Czartoski J, Mascola JR, Seaman MS, McElrath MJ, Doria-Rose NA, Klein F, Nussenzweig MC, Bjorkman PJ. 2019. Broad and potent neutralizing antibodies recognize the silent face of the HIV envelope. Immunity 50:1513-1529. DOI: https://doi.org/10.1016/j.immuni.2019.04.014, PMID: 31126879

Shibata R, Igarashi T, Haigwood N, Buckler-White A, Ogert R, Ross W, Willey R, Cho MW, Martin MA. 1999. Neutralizing antibody directed against the HIV-1 envelope glycoprotein can completely block HIV-1/SIV chimeric virus infections of macaque monkeys. Nature Medicine 5:204-210. DOI: https://doi.org/10.1038/5568, PMID: 9930869

Shingai M, Donau OK, Schmidt SD, Gautam R, Plishka RJ, Buckler-White A, Sadjadpour R, Lee WR, LaBranche CC, Montefiori DC, Mascola JR, Nishimura Y, Martin MA. 2012. Most rhesus macaques infected with the CCR5tropic SHIVAD8 generate cross-reactive antibodies that neutralize multiple HIV-1 strains. PNAS 109:1976919774. DOI: https://doi.org/10.1073/pnas.1217443109, PMID: 23129652

Shingai M, Nishimura Y, Klein F, Mouquet H, Donau OK, Plishka R, Buckler-White A, Seaman M, Piatak M, Lifson JD, Dimitrov DS, Nussenzweig MC, Martin MA. 2013. Antibody-mediated immunotherapy of macaques chronically infected with SHIV suppresses viraemia. Nature 503:277-280. DOI: https://doi.org/10.1038/ nature12746, PMID: 24172896

Simek MD, Rida W, Priddy FH, Pung P, Carrow E, Laufer DS, Lehrman JK, Boaz M, Tarragona-Fiol T, Miiro G, Birungi J, Pozniak A, McPhee DA, Manigart O, Karita E, Inwoley A, Jaoko W, Dehovitz J, Bekker LG,

Pitisuttithum $P$, et al. 2009. Human immunodeficiency virus type 1 elite neutralizers: individuals with broad and 
potent neutralizing activity identified by using a high-throughput neutralization assay together with an analytical selection algorithm. Journal of Virology 83:7337-7348. DOI: https://doi.org/10.1128/JVI.00110-09, PMID: 19439467

Sok D, Laserson U, Laserson J, Liu Y, Vigneault F, Julien JP, Briney B, Ramos A, Saye KF, Le K, Mahan A, Wang S, Kardar M, Yaari G, Walker LM, Simen BB, St John EP, Chan-Hui PY, Swiderek K, Kleinstein SH, et al. 2013. The effects of somatic hypermutation on neutralization and binding in the PGT121 family of broadly neutralizing HIV antibodies. PLOS Pathogens 9:e1003754. DOI: https://doi.org/10.1371/journal.ppat.1003754, PMID: 2427 8016

Sok D, Burton DR. 2018. Recent progress in broadly neutralizing antibodies to HIV. Nature Immunology 19: 1179-1188. DOI: https://doi.org/10.1038/s41590-018-0235-7, PMID: 30333615

von Boehmer L, Liu C, Ackerman S, Gitlin AD, Wang Q, Gazumyan A, Nussenzweig MC. 2016. Sequencing and cloning of antigen-specific antibodies from mouse memory B cells. Nature Protocols 11:1908-1923. DOI: https://doi.org/10.1038/nprot.2016.102, PMID: 27658009

Walker LM, Phogat SK, Chan-Hui PY, Wagner D, Phung P, Goss JL, Wrin T, Simek MD, Fling S, Mitcham JL, Lehrman JK, Priddy FH, Olsen OA, Frey SM, Hammond PW, Kaminsky S, Zamb T, Moyle M, Koff WC, Poignard $P$, et al. 2009. Broad and potent neutralizing antibodies from an african donor reveal a new HIV-1 vaccine target. Science 326:285-289. DOI: https://doi.org/10.1126/science.1178746, PMID: 19729618

Walker LM, Simek MD, Priddy F, Gach JS, Wagner D, Zwick MB, Phogat SK, Poignard P, Burton DR. 2010. A limited number of antibody specificities mediate broad and potent serum neutralization in selected HIV-1 infected individuals. PLOS Pathogens 6:e1001028. DOI: https://doi.org/10.1371/journal.ppat.1001028, PMID: 20700449

Walker LM, Huber M, Doores KJ, Falkowska E, Pejchal R, Julien JP, Wang SK, Ramos A, Chan-Hui PY, Moyle M, Mitcham JL, Hammond PW, Olsen OA, Phung P, Fling S, Wong CH, Phogat S, Wrin T, Simek MD, Koff WC, et al. 2011a. Broad neutralization coverage of HIV by multiple highly potent antibodies. Nature 477:466-470. DOI: https://doi.org/10.1038/nature10373, PMID: 21849977

Walker LM, Sok D, Nishimura Y, Donau O, Sadjadpour R, Gautam R, Shingai M, Pejchal R, Ramos A, Simek MD, Geng Y, Wilson IA, Poignard P, Martin MA, Burton DR. 2011b. Rapid development of glycan-specific, broad, and potent anti-HIV-1 gp120 neutralizing antibodies in an R5 SIV/HIV chimeric virus infected macaque. PNAS 108:20125-20129. DOI: https://doi.org/10.1073/pnas.1117531108, PMID: 22123961

Wang Z, Merkenschlager J, Chen ST, Oliveira TY, Ramos V, Gordon KM, Yao KH, Jankovic M, Nussenzweig M, Escolano A. 2020. Isolation of single HIV-1 envelope specific B cells and antibody cloning from immunized rhesus macaques. Journal of Immunological Methods 478:112734. DOI: https://doi.org/10.1016/j.jim.2019 112734, PMID: 31866284

Wardemann H, Yurasov S, Schaefer A, Young JW, Meffre E, Nussenzweig MC. 2003. Predominant autoantibody production by early human B cell precursors. Science 301:1374-1377. DOI: https://doi.org/10.1126/science. 1086907, PMID: 12920303

Wei X, Decker JM, Wang S, Hui H, Kappes JC, Wu X, Salazar-Gonzalez JF, Salazar MG, Kilby JM, Saag MS, Komarova NL, Nowak MA, Hahn BH, Kwong PD, Shaw GM. 2003. Antibody neutralization and escape by HIV-1. Nature 422:307-312. DOI: https://doi.org/10.1038/nature01470, PMID: 12646921

Xiao X, Chen W, Feng Y, Zhu Z, Prabakaran P, Wang Y, Zhang MY, Longo NS, Dimitrov DS. 2009. Germline-like predecessors of broadly neutralizing antibodies lack measurable binding to HIV-1 envelope glycoproteins: implications for evasion of immune responses and design of vaccine immunogens. Biochemical and Biophysical Research Communications 390:404-409. DOI: https://doi.org/10.1016/j.bbrc.2009.09.029, PMID: 19748484

Xu K, Acharya P, Kong R, Cheng C, Chuang GY, Liu K, Louder MK, O’Dell S, Rawi R, Sastry M, Shen CH, Zhang B, Zhou T, Asokan M, Bailer RT, Chambers M, Chen X, Choi CW, Dandey VP, Doria-Rose NA, et al. 2018. Epitope-based vaccine design yields fusion peptide-directed antibodies that neutralize diverse strains of HIV-1. Nature Medicine 24:857-867. DOI: https://doi.org/10.1038/s41591-018-0042-6, PMID: 29867235

Yamamoto T. 2015. Quality and quantity of TFH cells are critical for broad antibody development in SHIVAD8 infection. Science Translational Medicine 7:ra120. DOl: https://doi.org/10.1126/scitranslmed.aab3964

Yurasov S, Wardemann H, Hammersen J, Tsuiji M, Meffre E, Pascual V, Nussenzweig MC. 2005. Defective B cell tolerance checkpoints in systemic lupus erythematosus. Journal of Experimental Medicine 201:703-711. DOI: https://doi.org/10.1084/jem.20042251, PMID: 15738055

Zalevsky J, Chamberlain AK, Horton HM, Karki S, Leung IW, Sproule TJ, Lazar GA, Roopenian DC, Desjarlais JR. 2010. Enhanced antibody half-life improves in vivo activity. Nature Biotechnology 28:157-159. DOI: https://doi. org/10.1038/nbt.1601, PMID: 20081867

Zhang K. 2016. Gctf: real-time CTF determination and correction. Journal of Structural Biology 193:1-12. DOI: https://doi.org/10.1016/j.jsb.2015.11.003, PMID: 26592709

Zheng SQ, Palovcak E, Armache JP, Verba KA, Cheng Y, Agard DA. 2017. MotionCor2: anisotropic correction of beam-induced motion for improved cryo-electron microscopy. Nature Methods 14:331-332. DOI: https://doi. org/10.1038/nmeth.4193, PMID: 28250466

Zhou T, Georgiev I, Wu X, Yang ZY, Dai K, Finzi A, Kwon YD, Scheid JF, Shi W, Xu L, Yang Y, Zhu J, Nussenzweig MC, Sodroski J, Shapiro L, Nabel GJ, Mascola JR, Kwong PD. 2010. Structural basis for broad and potent neutralization of HIV-1 by antibody VRC01. Science 329:811-817. DOI: https://doi.org/10.1126/science. 1192819, PMID: 20616231

Zivanov J, Nakane T, Forsberg BO, Kimanius D, Hagen WJ, Lindahl E, Scheres SH. 2018. New tools for automated high-resolution cryo-EM structure determination in RELION-3. eLife 7:e42166. DOI: https://doi.org/ 10.7554/eLife.42166, PMID: 30412051 